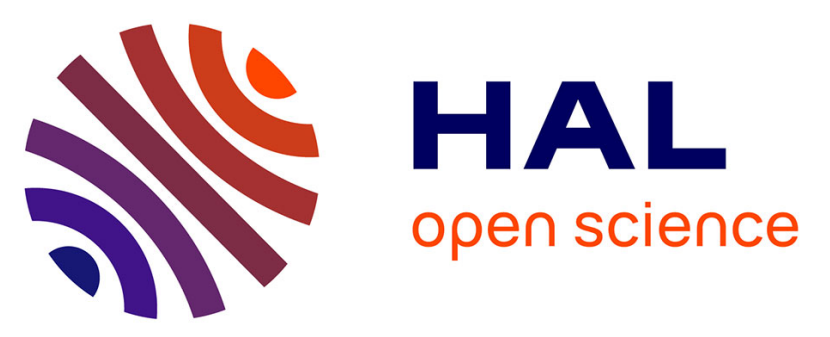

\title{
Pamir Plateau formation and crustal thickening before the India-Asia collision inferred from dating and petrology of the 110-92 Ma Southern Pamir volcanic sequence
}

Jovid Aminov, Lin Ding, Yunus Mamadjonov, Guillaume Dupont-Nivet, Jamshed Aminov, Li-Yun Zhang, Shokirjon Yoqubov, Javhar Aminov, Sherzod Abdulov

\section{- To cite this version:}

Jovid Aminov, Lin Ding, Yunus Mamadjonov, Guillaume Dupont-Nivet, Jamshed Aminov, et al.. Pamir Plateau formation and crustal thickening before the India-Asia collision inferred from dating and petrology of the 110-92 Ma Southern Pamir volcanic sequence. Gondwana Research, 2017, 51, pp.310-326. 10.1016/j.gr.2017.08.003 . insu-01579521

HAL Id: insu-01579521

https://hal-insu.archives-ouvertes.fr/insu-01579521

Submitted on 31 Aug 2017

HAL is a multi-disciplinary open access archive for the deposit and dissemination of scientific research documents, whether they are published or not. The documents may come from teaching and research institutions in France or abroad, or from public or private research centers.
L'archive ouverte pluridisciplinaire HAL, est destinée au dépôt et à la diffusion de documents scientifiques de niveau recherche, publiés ou non, émanant des établissements d'enseignement et de recherche français ou étrangers, des laboratoires publics ou privés. 


\section{Pamir Plateau formation and crustal thickening before the India-Asia collision inferred from dating and petrology of the 110-92 Ma Southern Pamir volcanic sequence.}

Jovid Aminov ${ }^{1,2,3 *}$, Lin Ding ${ }^{1}$, Yunus Mamadjonov ${ }^{3}$, Guillaume DupontNivet $^{4,5}$, Jamshed Aminov ${ }^{1,3}$, Li-Yun Zhang ${ }^{1}$, Shokirjon Yoqubov ${ }^{3}$, Javhar Aminov $^{6}$, Sherzod Abdulov ${ }^{1,3}$

${ }^{1}$ Key Laboratory of Continental Collision and Plateau Uplift, Institute of Tibetan Plateau Research, and Center for Excellence in Tibetan Plateau Earth Sciences, Chinese Academy of Sciences, Beijing 100101, China

${ }^{2}$ University of Chinese Academy of Sciences, Beijing 100049, China

${ }^{3}$ Institute of Geology, Earthquake Engineering and Seismology, Academy of Sciences of the Republic of Tajikistan, 267 Ayni Street, 734053, Dushanbe, Tajikistan

${ }^{4}$ Institute of Earth and Environmental Science, Potsdam University, KarlLiebknecht-Str. 24-25, 14476 Potsdam-Golm; Germany

${ }^{5}$ OSUR - Géosciences Rennes, CNRS UMR 6118, Université de Rennes1, Campus de Beaulieu, 35042 Rennes Cedex, France

${ }^{6}$ Xinjiang Institute of Ecology and Geography, Chinese Academy of Sciences, Urumqi, Xinjiang, China

*Corresponding author: Jovid Aminov (jovid.aminov@outlook.com) 


\section{Abstract}

The formation of the Pamir is a key component of the India-Asia collision with major implications for lithospheric processes, plateau formation, land-sea configurations and associated climate changes. Although the formation of the Pamir is traditionally linked to Cenozoic processes associated with the IndiaAsia collision, the contribution of the Mesozoic tectonic evolution remains poorly understood. The Pamir was formed by the suturing of Gondwanan terranes to the south margin of Eurasia, however, the timing and tectonic mechanisms associated with this Mesozoic accretion remains poorly constrained. These processes are recorded by several igneous belts within these terranes, which are not well studied. Within the Southern Pamir, the AlbianTuronian volcanic rocks and comagmatic plutons of the Kyzylrabat Igneous Complex (KIC) provide an important and still unconstrained record of the Pamir evolution. Here we provide the age, origin and the geodynamic setting of the KIC volcanics by studying their petrology, zircon U-Pb geochronology, geochemistry and isotope composition. 17 samples from the KIC volcanics yield $\mathrm{U}-\mathrm{Pb}$ ages spanning from 92 to $110 \mathrm{Ma}$. The volcanics are intermediate to acidic in composition $\left(\mathrm{SiO}_{2}=56-69\right.$ wt.\% $)$ and exhibit high-K calc-alkaline and shoshonitic affinity $\left(\mathrm{K}_{2} \mathrm{O} / \mathrm{Na}_{2} \mathrm{O}=1-2.2\right.$ wt. $\left.\%\right)$. They show enrichment in LILE and LREE and depletion in HFSE and HREE with negative Ta, $\mathrm{Ti}$ and $\mathrm{Nb}$ anomalies, suggesting an arc-related tectonic setting for their formation. Low 
$\varepsilon_{N d}(t)$ values (from -9.1 to -4.7 ), relatively high ${ }^{87} \mathrm{Sr}^{86} \mathrm{Sr}_{(\mathrm{i})}$ ratios $(0.7069-$ 0.7096 ) and broad range of zircon $\varepsilon_{\mathrm{Hf}}$ values (from -22.6 to -1.5 ) suggest a mixture of different magma sources. These features suggest that volcanics were derived by crustal under- or intraplating of an enriched subduction-related mantle shoshonitic magmas, by heating and partial melting of the lower crust, and by mixing of both magma components. Our results further imply that the KIC volcanics represent a shoshonitic suite typical of an evolution from active continental arc to post-collisional setting with a steepening of the Benioff zone and thickening of the crust toward the back-arc. This setting is best explained by the subduction - collision transition along the Shyok suture due to accretion of the Kohistan island arc to the Karakoram. This suggests that a significant part of the crustal shortening and thickening accommodated in the Pamir occurred in the Mesozoic before the India-Asia collision with implications for regional tectonic models. This further suggests the Pamir was already a major topographic feature with potentially important paleoclimate forcing such as the monsoonal circulation.

Keywords: Southern Pamir; Cretaceous; volcanic rocks; geochemistry; geochronology; petrogenesis 


\section{Introduction}

The crust of the Pamir, like Tibet, was formed as a result of amalgamation of several terranes during Paleozoic and Mesozoic times (Angiolini et al., 2013; Burtman and Samygin, 2001; Schwab et al., 2004; Yin and Harrison, 2000). Subsequently, in the Cenozoic, these amalgamated terranes were deformed by the India-Asia collision, making the reconstruction of the Mesozoic tectonic evolution of the Pamir difficult. It remains unclear how much of the convergence between these terranes and Asia can be assigned to the Cretaceous or the Cenozoic making reconstructions of observed crustal deformation unreliable (Robinson et al., 2015). Moreover, the preexisting Mesozoic structures are being reactivated guiding the Cenozoic to present day deformation (Cowgill, 2010). Thus, constraining of these structures is necessary for understanding the more recent tectonics of the region. The models of the Cenozoic tectonic evolution of the Pamir are still controversial. To account for the Cenozoic uplift of the Pamir some argue for post-collisional crustal delamination (Ivanova and Trifonov, 2005), but others for continental subduction (Burtman and Molnar, 1993; Kufner et al., 2016, Sobel et al., 2014), deciphering between which requires knowledge of the nature of the preexisting structures. In particular, the evolution of terrane accretion history and associated shortening and crustal thickening remains poorly constrained. The onset of Tethys subduction and subsequent Mesozoic terrane accretion may be 
responsible for the formation of significant topography in the region that may have influenced monsoonal intensity as well as the fluctuations of the protoParatethys epicontinental sea incursion into Central Asia. These processes, however, remain very poorly constrained in time and space.

The Mesozoic to Cenozoic magmatic rocks of the Pamir along with depositional setting of associated volcaniclastic strata can help to constrain the tectonics of the region. While several studies have addressed the Mesozoic tectonic history of the Pamir (e.g., Angiolini et al., 2013; Burtman and Molnar, 1993; Robinson, 2015; Schwab et al., 2004), Mesozoic igneous rocks in this region are not sufficiently studied, leading to variable interpretations of its tectonic evolution. The Southern Pamir is particularly important because it is ideally located in the terrane amalgamation zone. It has recorded the protracted suite of tectonic events in many Mesozoic to Cenozoic plutons (occasionally accompanied by eruptive volcanics) intruding its metamorphic rocks and Permian to Jurassic marine sedimentary sequences (Vladimirov et al., 1992; Meskhi, 1964). The study of the Mesozoic igneous rocks, especially their petrogenesis, magma source characteristics, and geodynamic setting contribute to understanding of the tectonic and paleogeographic setting of the Pamir terranes at the time of their emplacement or eruption.

In this study, we evaluate the petrology, whole-rock geochemical and $\mathrm{Sr}-\mathrm{Nd}$ isotopic compositions, mineral chemistry, zircon $\mathrm{U}-\mathrm{Pb}$ ages and $\mathrm{Hf}$ 
isotopic compositions of the volcanic rocks of the Kyzylrabat Igneous Complex (KIC) that were erupted in the Albian - Turonian time. The petrogenetic interpretations and zircon $\mathrm{U}-\mathrm{Pb}$ ages of the KIC volcanics provide a better understanding of the timing and nature of the magmatism of the Southern Pamir igneous belt. Utilizing the here presented data and previously proposed models of Mesozoic tectonic evolution of Asia, we discuss the petrogenesis and tectonic setting of the KIC volcanic rocks and propose a tectonic model for their formation. The presented model explains the Cretaceous paleogeography of the Pamir and tectonic processes that were active at the time. We finally discuss the model implications for the correlation of structures in Pamir-Tibet region, and paleogeographic and paleoclimatic evolution of the region.. 


\section{Geological setting}

From North to South, the Pamir - Karakoram region is divided into four tectonic regions: The Northern Pamir, Central Pamir, Southern Pamir and Karakoram. The Northern Pamir is separated from the Tian-Shan in the North by the Main Pamir Thrust. The boundary between the Northern and Central Pamir is represented by the south-directed Tanymas thrust, which in turn represents the western continuation of Jinsha (Palaeotethys) suture into the Pamir. The Southern Pamir is bounded to the north by the Rushan-Pshart suture and to the south by the Wakhan-Tirich boundary zone (Wakhan-TBZ) (Fig.1).

Defining the nature of these boundaries is key to understanding the tectonic evolution of the region, however, it remains enigmatic. While ophiolitic rocks have been documented along the Rushan-Pshart Suture (Shvolman, 1980) indicating an oceanic basin between the Central and the Southern Pamir, the Wakhan-TBZ is defined by a narrow belt of mantle peridotites, metagabbros and gneisses (Zanchi et al., 2000). The absence of an ophiolitic sequence sensu stricto along the Wakhan-TBZ led Zanchi et al. (2000) to the interpretation that it originated from a lower crust-upper mantle sequence, hence suggesting a subcontinental oceanic basin. The closure time of the Rushan-Pshart oceanic basin is still unclear. Several studies have suggested a late Jurassic - early Cretaceous age of collision between the Central and Southern Pamir (Burtman and Molnar, 1993; Pashkov and Shvolman, 1979; Schwab et al., 2004; 
Shvolman, 1978). This interpretation is based on documented deformation of Jurassic carbonates in the Central and Southern Pamir sealed by terrigenous Cretaceous sandstones and conglomerates (Ruzhentsev and Shvol'man, 1981; Shvolman, 1978). The late Jurassic - early Cretaceous age of collision is also supported by arc-related Jurassic plutons (200-160 Ma), exposed in the RushanPshart Zone (Leven, 1995; Schwab et al., 2004). However, a regional unconformity developed on strongly deformed upper Paleozoic and Triassic sediments, which is capped by red conglomerates and sandstones and conformably overlain by Hettangian limestones of the Gurumdi group was interpreted to support the late Triassic- early Jurassic age of suturing (Angiolini et al., 2013; Pashkov and Budanov, 1990; Robinson, 2015). The South dipping polarity of the thrusts along the Rushan-Pshart suture zone is generally interpreted as evidence for the south-directed polarity of subduction of the Rushan oceanic crust during its closure (e.g. Pashkov and Shvol'man, 1979; Burtman and Molnar, 1993; Angiolini et al., 2013; Robinson, 2015). However, a more convincing argument for South-directed subduction of Rushan oceanic crust beneath the Southern Pamir is the position of Triassic-Jurassic arc-related magmatic bodies (Budanov, 1964; Schwab et al., 2004) in the Rushan-Pshart zone. A different subduction polarity was proposed by Schwab et al. (2004), who depicted the polarity of the suture zone as North dipping, implying obduction of the Central Pamir onto the Southern Pamir. This interpretation is supported by ophiolite fragments that overly the Southern Pamir and according 
to Shvolman (1980), were emplaced as a result of obduction of the Central Pamir and Rushan Pshart zone onto the Southern Pamir. The closure of Wakhan basin is less understood and thought to have occurred slightly later after the closure of Rushan Ocean (Angiolini et al., 2013; Robinson, 2015). As suggested by Zanchi et al. (2000), welding of the Southern Pamir and the Western Karakoram may have been completed by the early Jurassic. The first granodioritic rocks were emplaced in the East Hindukush at this time (171 Ma) (Gaetani et al., 1996). Schwab et al., (2004) suggested that collision between the Karakoram and the Southern Pamir occurred at the end of the early Cretaceous. However, the early Cretaceous Tirich-Mir pluton intruding both - the Southern Pamir and Karakoram provides a strong evidence for a pre- Cretaceous Wakhan basin closure (Faisal et al., 2015, 2014; Heuberger et al., 2007; Zanchi and Gaetani, 2011).

The KIC is located in the Southern Pamir and is part of the Cimmerian superterrane, which includes the Central Pamir, Southern Pamir and Karakoram (Fig. 1). There are three points of view on the correlation of these Cimmerian terranes in the Pamir with those in Tibet; 1) that the Central and Southern Pamir together with the Karakoram terrane form the western continuation of the Qiangtang terrane (Angiolini et al., 2013; Burtman and Samygin, 2001; Robinson, 2015; Robinson et al., 2012), 2) that the Central Pamir correlates with the Qiangtang terrane, but the Southern Pamir and the Karakoram correlate with the Lhasa terrane (Burtman, 1994; Schwab et al., 
2004), and 3) that the Central Pamir correlates with Songpan-Ganze, Southern Pamir with Qiangtang and Karakoram with Lhasa terrane (Guillot and Replumaz, 2013; Searle and Tirrul, 1991).

It is generally interpreted that the Cimmerian superterrane detached from the Gondwanaland during the early Permian and drifted northward, finally accreting to the Eurasian margin by the late Triassic-early Jurassic (Angiolini et al., 2013; Angiolini et al., 2014; Gaetani, 1997; Zanchi and Gaetani, 2011; Zanchi et al., 2000). On its way to the north, the Cimmerian terrane was allegedly dissected into three blocks now represented by the Central Pamir, Southern Pamir and Karakoram.

After the Cimmerian accretion, further tectonic events have affected the area. The Karakoram is bounded to its South by the Shyok suture, which represents the remnants of the Shyok Ocean. This Ocean subducted beneath the Karakoram starting from the Middle Jurassic and closed as a result of accretion of the Kohistan Island arc to Eurasia in the late Cretaceous (Faisal et al., 2015) or even later in the Eocene (40 Ma; Bouilhol et al., 2013). The Northward polarity of subduction along the Shyok suture is evidenced by the Cretaceous arc-related magmatism in the Karakoram terrane (e.g. Faisal et al., 2015; Zanchi and Gaetani, 2011).

In the Cenozoic, the Southern Pamir (including the KIC studied here) was divided into the Southwestern and Southeastern Pamir by a regional system of Cenozoic extensional detachments developed along the flanks of 
large crustal domes, which formed along the pre-existing structures related to the Mesozoic terrane accretion (Angiolini et al., 2013; Pashkov and Budanov, 1990; Schwab et al., 2004; Stubner et al., 2013a; Stubner et al., 2013b). Metamorphic rocks with an Oligocene-Miocene high-grade metamorphic peak, which may represent the crystalline basement of the Southeastern Pamir, characterize the Southwestern Pamir (Schmidt et al., 2011; Stubner et al., 2013a; Stubner et al., 2013b).

\subsection{The Kyzylrabat Igneous Complex (KIC)}

The KIC includes the volcanic rocks and comagmatic plutons that are exposed, on both sides of Aksu River, in the southernmost part of the Murghab district of Tajikistan (Fig.1, Fig.2). It is part of an east-west trending magmatic belt of Mesozoic to Cenozoic plutons intruding the metamorphic rocks and late Paleozoic - Mesozoic sedimentary succession of the Southern Pamir (Fig. 1). Jurassic arc-type granitoids (Jizevsko-Khidjiskiy complex, 190$160 \mathrm{Ma}$ ) that intrude into the Eastern Pshart Permian to Jurassic oceanic-floorarc sequence in the North of the Southern Pamir are the oldest Mesozoic intrusives in this belt (Meskhi, 1964; Schwab et al., 2004; Shvol'man, 1977). The late Mesozoic magmatic rocks of this belt are represented by the Alichur, Seretash, Akjilga, Bazarryk, Akjar, Bazardara, Bashgumbas and Kyzylrabat (KIC) igneous complexes with ages of 110 - $80 \mathrm{Ma}$, which have been 
interpreted to be related to accretion-collision processes in the Southern Pamir (Vladimirov et al., 1990). The KIC is located in the Southern part of the Southeastern Pamir. It intrudes - a thick Permian to Middle Jurassic sedimentary succession, stacked into a polyphase Mesozoic-Cenozoic fold and thrust belt. In contrast to the rocks exposed in the western Southern Pamir, this succession represents unmetamorphosed upper crustal rocks (Angiolini et al., 2013; Angiolini et al., 2014; Dronov, 2003; Dufour et al., 1958).

\subsection{Description of KIC volcanics}

The KIC volcanics consist of the connected Beik and Teshiktash lava sequences, with the Salangur lava flow branching from the latter lava sequence (Fig. 2a). Volcanic rocks lie on the lower and middle Jurassic limestones (Budanov et al., 1999; Dronov and Bronnikova, 1988; Puzankov et al., 2000; Titov et al., 1996). A layer of conglomerates crops out at the base of the best-preserved sections of volcanic rocks (Fig.3a), which unconformably lies on the Jurassic deposits. The KIC volcanics are intruded by the KIC monzonites and monzodiorites, and the Alichur granodiorites in the south of the Beik sequence (Fig. 2). The total thickness of the KIC volcanic rocks is given by different authors varying between 1200 and $2400 \mathrm{~m}$. The KIC volcanics are depicted in all the maps as a single unit without detailed mapping. 
Based on our observations, the KIC volcanics can be divided into three formations from bottom to top: the Ganjibay, Julbeles and Tashbulak formations. The lower - Ganjibay formation consists of gray and reddish lavas, tuffic lavas and tuff breccias of dacitic composition. The rocks of this formation conformably lie on the reddish conglomerates with differently sized (up to 20$30 \mathrm{~cm}$ ) clasts of limestones and sandstones (Fig. 3a). Along a tributary of the Kyzylrabat River, interlayering of conglomerates with volcanics has been observed, which supports conformable contact of the volcanics with the conglomerates. The angular clasts in the tuffic breccias consist of plagioclase crystals of different size $(2 \mathrm{~mm}-2 \mathrm{~cm})$, which are distributed chaotically. The Julbeles formation consists of black and gray lavas, gray tuffs and brownish tuff breccias of basaltic andesite, andesite, dacite, latite and Q-latite composition. The brownish tuff breccias crop out at the top of the section with the angular clasts consisting of K-feldspar and pyroxene $(3 \mathrm{~mm}-1 \mathrm{~cm})$. The appearance of K-feldspar in the clasts probably indicates a change in the magma composition. The upper, Tashbulak formation, is composed of black lavas, gray to greenish, brownish and yellowish tuffs and tuff breccias of dacite, latite, Q-latite and rhyolite composition. The clasts in the tuff breccias consist of plagioclase, Kfeldspar and biotite. The occasional pores in the black lavas are locally filled by calcite.

Previous studies of the KIC volcanics have addressed the geological structure, stratigraphy, petrogeochemistry and age of the rocks. 
However, the magma origin and evolution, as well as the tectonic position of the rocks is still unclear. Previous whole-rock and mineral (plagioclase, amphibole and biotite) Rb-Sr (Titov et al., 1996) and K-Ar (Meskhi, 1974) datings of the rocks yielded ages of 108-110 Ma and 107 - 130 Ma respectively. In this study, we provide first state-of-the-art single grain zircon U-Pb dating from 17 rock samples and address the petrogenesis and tectonic position of these volcanics in order to infer the tectonic setting of the Southern Pamir during the early to late Cretaceous. 


\section{Petrography}

In this study, we analyzed 43 volcanic samples collected from KIC. Phenocryst and groundmass composition of the rock samples are shown in Table 1.

\subsection{Ganjibay formation}

The gray lavas of Ganjibay formation have a porphyritic texture with $40 \%$ of phenocrysts represented by plagioclase (40\%), biotite (30\%), amphibole (20\%) and clinopyroxene (10\%). However, clinopyroxene phenocrysts appear mainly in rounded clasts that were captured by lava (Fig. 3e). These clasts consist of anhedral crystals of plagioclase, biotite, amphibole and clinopyroxene. The groundmass of these rocks is cryptocrystalline. The gray tuffs and tuff breccias are porphyritic in texture with phenocrysts (30 $50 \%$ ) represented by subhedral to anhedral plagioclase and angular to rounded xenocrysts of plagioclase, biotite, quartz and calcite in a cryptocrystalline groundmass (50-70\%; Fig. 3g). The reddish tuffs of the Ganjibay formation have a porphyritic texture with $50-55 \%$ phenocrysts, which are represented by anhedral to subhedral plagioclase and biotite phenocrysts and their angular clasts (Fig. 3b, h). Small amphibole and clinopyroxene phenocrysts as well as quartz xenocrysts were also observed. The groundmass of these rocks is also 
cryptocrystalline. In all the rocks of this formation, many phenocrysts of plagioclase and biotite are altered by sericite and chlorite respectively.

\subsection{Julbeles formation}

The lavas of the Julbeles formation are gray to black in color with $40-50 \%$ of phenocrysts in a fine-grained groundmass. The phenocrysts consist of euhedral to subhedral plagioclase (50\%), biotite (30\%), amphibole (15\%) and minor clinopyroxene ( 5\%; Fig. 3c, i). Orthopyroxene and quartz phenocrysts can also be observed in small amount. Plagioclase phenocrysts show simple and polysynthetic twinning, and sometimes form big glomerocrysts. Some of plagioclase phenocrysts show oscillatory zoning. The gray tuffs of the Julbeles formation have a porphyritic texture with $30-40 \%$ of phenocrysts that are mainly represented by plagioclase (50-60\%) and clinopyroxene (20-25\%) with some of them containing biotite $(\sim 5 \%)$. They also have angular clasts of xenogenic quartz and calcite ( 20\%). Most of the biotite phenocrysts are altered by chlorite, whereas some of the plagioclase phenocrysts are altered by sericite. The brownish tuff breccias have a porphyritic texture with coarse (up to $5 \times 2$ $\mathrm{mm})$ to medium grained phenocrysts $(30-40 \%)$ that mainly consist of $\mathrm{K}$ feldspar, plagioclase, clinopyroxene, amphibole and very few biotites. Plagioclase phenocrysts show oscillatory zoning and sometimes form big glomerocrysts. K-feldspar phenocrysts are euhedral, large (up to $5 \times 2 \mathrm{~mm}$ ) and 
elongate with inclusions of clinopyroxene, apatite and magnetite in them (Fig. 3j). Some plagioclase and clinopyroxene phenocrysts are altered by sericite and chlorite respectively. The clasts in tuff breccias are composed of broken angular fragments of K-feldspar and angular to rounded clasts that consist of clinopyroxene and plagioclase.

\subsection{Tashbulak formation}

The black lavas of the Tashbulak formation show a porphyritic texture with euhedral to subhedral phenocrysts $(30-40 \%)$ of plagioclase $(50 \%)$, biotite $(25 \%)$ and amphibole $(\sim 25 \%)$. Also, a few phenocrysts of clinopyroxene and orthopyroxene were observed $(\sim 1-5 \%)$. The groundmass $(60-70 \%)$ in these rocks is cryptocrystalline. Tuff breccias of the Tashbulak formation are gray to greenish (Fig. 3d) and brownish in color and have a porphyritic texture. Angular clasts of the breccias are represented by broken fragments of plagioclase. They contain phenocrysts $(20-30 \%)$ of plagioclase (50 -60\%), clinopyroxene (35-40\%) and Quartz (up to 15\%) in a fine-grained groundmass (70-80\%) (Fig. 3k). Tuffs of this formation are gray and yellowish in color with

a porphyritic texture. Plagioclase (40\%), K-feldspar (30\%), clinopyroxene (10\%), biotite (10\%) and amphibole ( $5 \%)$ phenocrysts (30-40\%) are embedded in a fine-grained groundmass (60-70\%). Tuffs that have rhyolitic composition (BK3.1 and BK3.2) contain numerous resorbed xenocrysts of calcite and quartz 
$(\sim 5 \%)$. The quartz xenocrysts often show corroded margins and are surrounded by reaction rims of fine-grained feldspars (Fig. 3m), which indicate disequilibrium of the quartz crystals with the surrounding magma, caused by changes in melt pressure or chemical composition (Sarjoughian et al., 2012). 


\section{Analytical Results}

Analytical methods for the results provided here are described in the supplementary Text $\mathrm{S} 1$.

\subsection{Whole-rock geochemistry}

Representative major and trace element compositions of KIC volcanic rocks are given in Table 2; for compositions of all the analyzed samples, please refer to the supplementary Table S1. The rocks of the Ganjibay formation show loss on ignition (LOI) of 0.64 wt.\% to 3.93 wt.\% with an average of 2.69 wt.\% suggesting relative freshness of the samples. The $\mathrm{SiO}_{2}$ content of these samples ranges from $62 \mathrm{wt} . \%$ to $65 \mathrm{wt} . \%$ with the total alkali content and $\mathrm{K}_{2} \mathrm{O} / \mathrm{Na}_{2} \mathrm{O}$ ratios ranging from 6.24 wt. $\%$ to 6.59 wt. $\%$ and 0.95 to 1.55 respectively. The samples show high $\mathrm{Al}_{2} \mathrm{O}_{3}$ content $(15.2-16.5$ wt.\%) with alumina saturation index (ASI or $\mathrm{A} / \mathrm{CNK}$, molecular ratio of $\left(\mathrm{Al}_{2} \mathrm{O}_{3} /\right.$ $\left.\left.\left(\mathrm{CaO}+\mathrm{Na}_{2} \mathrm{O}+\mathrm{K}_{2} \mathrm{O}\right)\right]\right)$ varying over a range of $0.97-1.08$. Total iron $\left(\mathrm{Fe}_{2} \mathrm{O}_{3} ; 3.8\right.$ wt.\% - 5.4 wt. \%) and $\mathrm{MgO}(1.5$ wt.\% - 2.8 wt.\%) contents vary over a relatively narrow range with magnesium number $(\mathrm{Mg \#})$ of $41-56$. The concentration of $\mathrm{TiO}_{2}$ in these samples is low varying from $0.50 \mathrm{wt} . \%$ to 0.70 wt.\%.

The samples from the Julbeles formation are mostly fresh showing low LOI, which ranges from 0.56 wt.\% to 3.39 wt.\% with an average of 1.38 $\mathrm{wt} \%$. The $\mathrm{SiO}_{2}$ content of the samples is distributed within a relatively broad 
range, stretching from $56 \mathrm{wt} . \%$ to $64 \mathrm{wt} . \%$. Their total alkali content in contrast with that of the Ganjibay formation varies broadly ranging from $5.64 \mathrm{wt} \%$ to 8.35 wt. $\%$ with $\mathrm{K}_{2} \mathrm{O} / \mathrm{Na}_{2} \mathrm{O}$ ratios of $1.07-2.27$. The $\mathrm{Al}_{2} \mathrm{O}_{3}$ content is high (1416.6) with ASI in a range of $0.77-1.07 . \mathrm{Fe}_{2} \mathrm{O}_{3}(4.6-7.8$ wt. $\%)$ and $\mathrm{MgO}(2-$ 5.5 wt.\%) contents of the samples vary over a broad range with Mg\# ranging from 46 to $58 . \mathrm{TiO}_{2}$ content is low, which is distributed within a range of 0.58 wt. $\%-0.94$ wt. $\%$.

The rock samples of the Tashbulak formation show LOI ranging from 0.64 wt. $\%$ to 3.45 wt. $\%$ with an average of $1.72 \mathrm{wt} \% . \mathrm{SiO}_{2}(59-69 \mathrm{wt} . \%)$ and total alkali $(6.22-9.84$ wt.\%) contents of these samples are high with $\mathrm{K}_{2} \mathrm{O} / \mathrm{Na}_{2} \mathrm{O}$ ratios ranging from 1.26 to $2.02 . \mathrm{Al}_{2} \mathrm{O}_{3}$ content varies from 14.4 wt. $\%$ to 16.4 wt. $\%$ and ASI ranges from 0.79 to $1.12 . \mathrm{Fe}_{2} \mathrm{O}_{3}$ ranges from 3.19 wt. $\%$ to 6.21 wt. $\%$ and $\mathrm{MgO}: 0.28$ - 3.77 wt.\% with a wide range of $\mathrm{Mg \#} \mathrm{-} 14$ 55. $\mathrm{TiO}_{2}$ content is low showing a range of $0.30-0.80 \mathrm{wt} . \%$.

The rocks are classified, on an anhydrous basis, as andesite, dacite, latite, quartz latite and rhyolite (Le Maitre et al., 1989) (Fig. 4a). This classification scheme also demonstrates that most samples are of subalkaline affinity, with only few of them showing alkaline nature. On the diagram of $\mathrm{SiO}_{2}$ vs. $\mathrm{K}_{2} \mathrm{O}$, the $\mathrm{KIC}$ volcanic rocks plot within High-K calc-alkaline and shoshonite series (Fig. 4b).

Primitive mantle-normalized variation diagram shows that all the volcanics have uniform patterns and are characterized by enrichment of Large 
Ion Lithophile Elements (LILE) and depletion of High Field Strength Elements (HFSE). The rocks also show negative anomalies of $\mathrm{Nb}, \mathrm{Ta}, \mathrm{P}, \mathrm{Sr}$ and $\mathrm{Ti}$ and positive anomalies of $\mathrm{Pb}, \mathrm{U}$ and $\mathrm{Th}$ (Fig. 5a-c). The total rare earth element (REE) concentrations of samples range from 117 to $233 \mathrm{ppm}$ with an average of $174 \mathrm{ppm}$. The rocks show enrichment in light rare earth elements (LREE) and depletion in heavy rare earth elements $(\mathrm{HREE})\left[(\mathrm{La} / \mathrm{Yb})_{\mathrm{n}}=8.5-16.8\right]$, with negative $\mathrm{Eu}$ anomalies $\left(\mathrm{Eu} / \mathrm{Eu}^{*}=0.51-0.75\right.$; Fig. 5d-f), which suggests that plagioclase was a major phase controlling magmatic differentiation.

$\mathrm{Sr}$ and Nd isotopic data (Table 3 and Fig. 6) from the KIC volcanic rocks yielded ${ }^{87} \mathrm{Sr}^{86} \mathrm{Sr}_{(\mathrm{i})}$ ratios of $0.7069-0.7096$ and $\varepsilon_{\mathrm{Nd}}(\mathrm{t})$ ranging from -9.1 to -4.7 . Depleted mantle model ages range from 1.1 to $1.44 \mathrm{Ga} . \varepsilon_{\mathrm{Nd}}(\mathrm{t})$ values plotted against ${ }^{87} \mathrm{Sr}^{86} \mathrm{Sr}_{(\mathrm{i})}$ ratios show that the KIC volcanic rocks exhibit isotopic features of a mixed magma with the rocks of the Julbeles formation having higher $\varepsilon_{\mathrm{Nd}}(\mathrm{t})$ values than the other two formations (Fig.6). Our $\mathrm{Sr}$ and $\mathrm{Nd}$ isotopic results are consistent with the previous study on other Cretaceous plutonic rocks sampled from the Southern Pamir (Schwab et al., 2004).

\subsection{Mineral chemistry}

The chemical composition and structural formulae of minerals of the rock samples from the Julbeles and Tashbulak formations are shown in Tables S2a-e. Plagioclase compositions of the samples from the Julbeles formation vary between $\mathrm{An}_{33}-\mathrm{An}_{85}$ and plot in the ternary diagram as bytownite 
- labradorite - andesine (Fig. 7a). Potassium feldspar is represented by orthoclase with Or content between 78 and 98. The chemical composition of plagioclase phenocrysts from the Tashbulak samples vary over a range of $\mathrm{An}_{43}-$ $\mathrm{An}_{74}$. The K-feldspar phenocrysts in these samples have not been measured.

Biotite phenocrysts of analyzed samples show high $\mathrm{TiO}_{2}$ content (Julbeles: $3.58-5.75$ and Tashbulak: $4.39-4.47$ wt.\%) which according to Nachit et al. (2005) indicates that they are primary magmatic biotites. On the $\mathrm{Al}^{\mathrm{IV}}$ vs. $\mathrm{Fe}^{2+} /\left(\mathrm{Fe}^{2+}+\mathrm{Mg}\right)$ diagram of Rieder et al. (1998) biotites classify into the phlogopite end-member (Fig. 7e). The alumina saturation index (ASI $\left[\mathrm{Al}^{\mathrm{T}} /(\mathrm{Ca}+\mathrm{Na}+\mathrm{K})\right]$ is also low in biotites for both formations (Julbeles: $1.27-$ 1.82; Tashbulak: $1.42-1.44)$ reflecting lower alumina activity in the magma (Sarjoughian et al., 2012). On the plot of $\mathrm{Fe}^{2+} /\left(\mathrm{Fe}^{2+}+\mathrm{Mg}\right)$ vs. $\mathrm{Al}^{\mathrm{IV}}$ biotites plot in the field of shoshonitic granites (Fig.7f), indicating their affinity to be related with shoshonitic magma.

The analyzed clinopyroxene phenocrysts of both formations, classified on the Wo-En-Fs ternary diagram, correspond to diopside - augite (Fig. 7b). Association of diopside - augite is a characteristic of shoshonitic rocks (Morrison, 1980). Mg\# of the clinopyroxene phenocrysts is high and varies over the range of $0.50-0.88$. Some of the clinopyroxene phenocrysts show oscillatory zoning in $\mathrm{Al}, \mathrm{Fe}, \mathrm{Mg}$ contents, consistent with the crystal growth. 
Amphibole phenocrysts from the Julbeles formation that yield $\mathrm{Na}+\mathrm{K} \geq 0.5$ based on amphibole classification diagrams of Leake et al. (1997) and Hawthorne and Oberti (2007) classify as magnesio-hastingsite (IVAl<Fe3+) and pargasite (IVAl $>\mathrm{Fe} 3+)$ (Fig.7c). The amphibole phenocrysts of samples from the Tashbulak formation with higher content of alkaline elements $(\mathrm{Na}+\mathrm{K} \geq 0.5)$ classify as magnesio-hastingsite (IVAl $<\mathrm{Fe} 3+)$ (Fig.7c). Only three analyses show high content of $\mathrm{Si}(>6.5)$ and classify as Edenite. The amphibole phenocrysts from both formations with lower content of alkaline elements $(\mathrm{Na}+\mathrm{K}<0.5)$ classify as magnesio-hornblende (Fig. $7 \mathrm{~d})$. As it is shown on the classification diagrams, amphiboles are calcic and this implies that the rocks have I-type affinity. Some amphibole phenocrysts that demonstrate zoning (Fig. 31) vary in composition from the center of the crystal to its edge. Consistently, the $\mathrm{SiO}_{2}$ composition increases from $41.80 \mathrm{wt} \%$ to $47.89 \mathrm{wt} \%$. The contents of $\mathrm{TiO}_{2}(3.20-1.17 \mathrm{wt} \%), \mathrm{Al}_{2} \mathrm{O}_{3}(12.25-6.95 \mathrm{wt} \%)$, and $\mathrm{CaO}(11.29-10.71$ wt\%) decrease, whereas that of $\mathrm{MgO}(10.59-11.94 \mathrm{wt} \%)$ and $\mathrm{FeO}(15.06-$ $17.00 \mathrm{wt} \%$ ) slightly increase.

4.3.Zircon $\mathrm{U}-\mathrm{Pb}$ geochronology and Lu-Hf isotopic compositions

Zircon U-Pb geochronological data of 17 samples are summarized in Table 1 and shown in Table S3. Zircon grains are subhedral to euhedral with lengths between $80-300 \mu \mathrm{m}$ and aspect ratios of 1:1 to 4:1 (Fig. S1). Most zircons show oscillatory zoning patterns. They have U content of 71.4 to 3290 
ppm with $\mathrm{Th} / \mathrm{U}$ ratios of $0.13-2.47(>0.1)$, indicating a magmatic origin (Hoskin and Schaltegger, 2003). Some inherited cores are also observed. From 472 measured zircon grains (18 samples) 293 of them yielded concordant ages within $90-110 \%$ of concordance (Table S3), which are used in age calculations. 286 of the measured zircon grains from 17 analyzed samples yielded ${ }^{206} \mathrm{~Pb} /{ }^{238} \mathrm{U}$ ages of $88.2 \pm 8.4-121 \pm 14$ Ma with calculated weighted mean ages for individual samples ranging from $91.8 \pm 1.9$ to 109.6 $\pm 1.7 \mathrm{Ma}$ (Table 1; Fig. S2). 7 zircon grains yielded inherited ages of $133 \pm 8.9-147.1 \pm 9.9 ; 223 \pm 15$; $304 \pm 18 ; 459 \pm 40-466 \pm 27 ; 698 \pm 28$ Ma. Our U-Pb ages are consistent with previous $\mathrm{Rb}-\mathrm{Sr}$ dating of KIC volcanic rocks (108-110 Ma) (Titov et al., 1996).

Hf isotopic data are shown in Table 1 and Table S4. Zircon grains from the samples of the Ganjibay formation yielded initial ${ }^{176} \mathrm{Hf} /{ }^{177} \mathrm{Hf}$ ratios of 0.282273 to 0.282496 with $\varepsilon_{\mathrm{Hf}}(\mathrm{t})$ values ranging between -14 and -2.9 and $T_{D M}^{C}$ ages varying from 1.642 to $2.029 \mathrm{Ga}$. Zircon grains from the samples of the Julbeles formation yielded lower initial ${ }^{176} \mathrm{Hf} /{ }^{177} \mathrm{Hf}$ ratios ranging from 0.281978 to 0.282680 with $\varepsilon_{\mathrm{Hf}}(\mathrm{t})$ values ranging between -22.6 and -1.5 , and $T_{D M}^{C}$ ages that vary between 1.229 and $2.568 \mathrm{Ga}$. The samples from the Tashbulak formation yielded zircon initial ${ }^{176} \mathrm{Hf} /{ }^{177} \mathrm{Hf}$ ratios distributed over a range of $0.282323-0.282561, \varepsilon_{\mathrm{Hf}}(\mathrm{t})$ values vary between -14.2 and -5.7 with $T_{D M}^{C}$ ages of $1.499-2.033 \mathrm{Ga}$. 


\section{Discussion}

\subsection{Petrogenesis}

\subsubsection{Magma evolution}

Partial melting of the source region can be identified by the ratio of the concentration of a highly incompatible element to a moderately incompatible element (Schiano et al., 2010). The KIC volcanic rocks exhibit a linear trend on a $\mathrm{La} / \mathrm{Yb}$ vs La diagram, indicating that the primary magma was generated by partial melting of the source materials (Fig. 8g) (Ding et al., 2003). To evaluate fractional crystallization of a magma the Harker diagrams as well as the ratio of the concentrations of highly incompatible to moderately incompatible elements can be used (Allègre and Minster, 1978; Ding et al., 2003; Li et al., 2013; Zhang et al., 2014). KIC volcanic rocks have low Mg\# (14 - 58) and low compatible element $(\mathrm{Cr}, \mathrm{Ni})$ concentrations, suggesting that the chemical variations of rocks were controlled by fractional crystallization during magma evolution. Olivine and clinopyroxene fractionation is responsible for decrease of $\mathrm{Ni}$ and $\mathrm{Cr}$ respectively with increasing differentiation. This is supported by negative correlation of $\mathrm{MgO}$ with $\mathrm{SiO}_{2}$ and positive correlation of $\mathrm{Fe}_{2} \mathrm{O}_{3}$ and $\mathrm{Cr}$ with $\mathrm{MgO}$, indicating fractionation of mafic minerals (Fig. 8a-c). Low Sc (3-31 ppm) content suggests fractional crystallization of clinopyroxene (Li et al., 2013). Tb has higher partition coefficient in clinopyroxene and amphibole in comparison with La (Bacon and Druitt, 1988), hence fractionation 
of these minerals will increase the $\mathrm{La} / \mathrm{Tb}$ ratio. The $\mathrm{KIC}$ volcanic rocks show a linear trend on a $\mathrm{SiO}_{2}$ versus $\mathrm{La} / \mathrm{Tb}$ plot, suggesting fractionation of clinopyroxene and amphibole (Fig.8e). Moreover, they also show a linear trend on a $\mathrm{SiO}_{2}$ versus $\mathrm{Zr} / \mathrm{Sm}$ diagram, indicating fractional crystallization of amphibole (Fig. 8f) (Zhang et al., 2014). In addition, the negative correlation of $\mathrm{CaO}$ and $\mathrm{SiO}_{2}$ (Fig. 8d), negative anomalies of Eu, Sr, and $\mathrm{Ba}$ (Fig. 5a-f), varying composition of plagioclase from bytownite to andesine (Fig. 7a) suggest plagioclase fractionation. Plot of $\mathrm{Rb}$ vs $\mathrm{Ba}$ (Fig. 8i) allows evaluation of the relative importance of fractionation of plagioclase, clinopyroxene or amphibole in the evolution of the KIC magmas. These interpretations are consistent with petrographic features of the rocks, which contain plagioclase, clinopyroxene and amphibole phenocrysts. The low $\mathrm{Ba}$ and Sr concentrations, pronounced $\mathrm{Eu}$ negative anomalies and abundant plagioclase phenocrysts indicate that a major phase of the magmatic evolution occurred at a relatively shallow level. Plagioclase phenocrysts display obvious oscillatory zoning, which is suggestive of relatively slow ascent or retention within a shallow chamber (Chen et al., 2015). Quartz and calcite resorbed xenocrysts observed in rhyolites indicate contamination of magma by crustal material in this shallow magma chamber during the late stages of eruption. Thus, our geochemical results suggest that the KIC magma evolution is mainly controlled by partial melting and fractional crystallization of originally mafic material that occurred 
at a relatively shallow level after relatively slow ascent or retention within a shallow chamber.

\subsubsection{Magma source}

The KIC volcanics are shoshonitic and derived by mixing of two magmas. The high $\mathrm{K}_{2} \mathrm{O}$ content and high $\mathrm{K}_{2} \mathrm{O} / \mathrm{Na}_{2} \mathrm{O}$ ratios are distinctive features of shoshonitic series rocks. The latter ratios in shoshonitic rocks are commonly between 1 and 2.5. The $\mathrm{KIC}$ volcanic rocks plot on the $\mathrm{K}_{2} \mathrm{O}$ vs $\mathrm{SiO}_{2}$ diagram (Fig. 4b) within two adjacent fields: High-K calc-alkaline and shoshonitic with $\mathrm{K}_{2} \mathrm{O} / \mathrm{Na}_{2} \mathrm{O}$ ratios of $1-2.2$. Although, high $\mathrm{K}_{2} \mathrm{O} / \mathrm{Na}_{2} \mathrm{O}$ ratios suggest a shoshonitic affinity, which indicates a mantle source for the KIC volcanics, the transition between two series of rocks suggests that the KIC magmas were derived by mixing of two magma components. This is because a parent magma with a given $\mathrm{K}_{2} \mathrm{O}$ and $\mathrm{SiO}_{2}$ content will usually evolve within the same particular field, and for a magma to evolve into an adjacent field, the process of mixing of two magma types must operate (Roberts and Clemens, 1993). An arcuate trend on the plot of La/Sm vs La (Fig. 8h) also indicates the mixed character of the KIC magmas (Schiano et al., 2010).

The KIC volcanics are not purely crustal. They yielded $10-27 \%$ CIPW normative quartz, which is also observed as phenocryst and in the groundmass of some samples suggesting that they are quartz-saturated and could be derived by melting of a crustal source. However, Hermann and 
Spandler (2008) in their experimental studies demonstrated that partial melting of typical crustal rocks, over a large range of pressures and temperatures, produces peraluminous granitic melts with $\mathrm{K}_{2} \mathrm{O} / \mathrm{Na}_{2} \mathrm{O}$ ratios close to unity at crustal pressures. A different study also suggested that pure crustal melts would lead to formation of only peraluminous leucogranites (Douce, 1999), which is not the case with the KIC volcanics. Moreover, the high $\mathrm{Mg}$ and $\mathrm{Ca}$ contents of biotite and plagioclase phenocrysts, respectively, exclude the derivation of magmas by only partial melting of lower crustal rocks, because in this case plagioclase phenocrysts would be represented by more acidic members (andesine - albite) and biotite would be ferroan.

The isotopic features of the KIC volcanic rocks are also consistent with mixing of mantle shoshonitic and crustal felsic magmas. Whole-rock $\varepsilon_{\mathrm{Nd}}(\mathrm{t})$ and zircon $\varepsilon_{\mathrm{Hf}}(\mathrm{t})$ values of rocks are negative, reflecting recycling of continental crust. Zircon $\varepsilon_{\mathrm{Hf}}(\mathrm{t})$ values plotted against the U-Pb ages (Fig.9) of zircon grains suggest that samples from the Julbeles formation, plotting close to the CHUR line and those samples that yielded lower $\varepsilon_{\mathrm{Hf}}(\mathrm{t})$ values, may represent two distinct magma sources that mixed on the crustal level. The whole-rock $\varepsilon_{\mathrm{Nd}}(\mathrm{t})$ values plotting close to OIB (Fig. 6), and zircon $\varepsilon_{\mathrm{Hf}}(\mathrm{t})$ values of latites and quartz latites plotting close to the CHUR line, are consistent with mixing of mantle shoshonitic and crustal felsic magmas. Mixing between shoshonitic and felsic magmas is also consistent with uniform patterns of trace elements, which requires two end-members to have similar trace element patterns. Therefore, we 
suggest that the KIC magmas were derived by mixing between mantle shoshonitic and crustal felsic magmas and further on evolved by fractional crystallization in the magma chambers, which led to the formation of more evolved varieties of the KIC volcanic rocks. This interpretation is consistent with a previous study of the volcanic rocks of the Southern Pamir (Puzankov et al., 2000), which suggested a mafic (shoshonitic) component for the KIC primary magmas.

\subsection{Tectonic setting}

There is a general consensus that shoshonitic rocks are derived from partial melting of mantle that had been metasomatized by subductionrelated fluids or melts (Campbell et al., 2014; Edgar and Arima, 1985; Foley and Peccerillo, 1992; Morrison, 1980; Peccerillo, 1990; Turner et al., 1996). The hypothesis that melting of a hydrous mantle can produce potassic magmas is supported by the available experimental evidence (Sekine and Wyllie, 1982). Other hypotheses also exist to explain the origin of the Tibetan and Karakoram Cenozoic high-potassic magmas. They include subduction of continental crust (Deng, 1998), convective removal of the mantle lithosphere (Turner et al., 1996; Miller et al., 1999; Küster et al., 1998), extension along strike-slip faults (Yin et al., 1995), slab breakoff (Miller et al., 1999; Mahéo et al., 2009), and melting of a crustal block that has been thrusted into the upper mantle (Campbell et al., 2014). However, based on our results, the KIC volcanics are more likely 
associated with subduction processes. They display features similar to results of Meen, (1987) from shoshonites from the Absaroka volcanic field. Meen, (1987) suggested that shoshonitic magma can be derived by high pressure fractional crystallization of an anhydrous tholeiitic basalt magma above the deeper part of the Benioff zone. He also indicated that the transition between tholeiitic and shoshonitic magma can be related to thickening of crust toward the back-arc.

We interpret that the KIC volcanics record a steepening of the Benioff zone and thickening of the crust toward the back-arc during northward subduction of the Tethyan ocean. They are represented by a range of intermediate to acidic rocks $(\mathrm{SiO} 2=56-69 \mathrm{wt} \%)$ that exhibit High-K calcalkaline and shoshonitic affinity (Fig. 4b), having high $\mathrm{K}_{2} \mathrm{O} / \mathrm{Na}_{2} \mathrm{O}$ ratios $(\geq 1$ ), high $\mathrm{Na}_{2} \mathrm{O}+\mathrm{K}_{2} \mathrm{O}(>5$ wt.\%) and low $\mathrm{TiO} 2(<1$ wt \%), similar to typical shoshonitic series (Joplin, 1968; Morrison, 1980). K-rich magmatism, such as shoshonites, is inferred to be formed in a variety of tectonic settings including oceanic arc, continental arc and postcollisional arc settings. The shoshonitic rocks in these tectonic settings are regarded as products of magmatic activity above a subduction zone, where they are related to the melting of a phlogopitebearing wedge (Muller et al., 1997). In a subduction-related tectonic setting the shoshonites are associated with calc-alkaline suites. In this case, they are generated from the Low-K tholeiitic and calc-alkaline rocks, occurring above the deeper part of the Benioff zone, and therefore K-enrichment is usually 
related to steepening of this zone and thickening of the crust toward the back$\operatorname{arc}$ (Morrison, 1980; Meen, 1987).

Enrichment in large ion lithophile elements (LILE; e.g. Rb, Th, U) and depletion in high field strength elements (HFSE; e.g. Ta, Nb, Ti) alongside with high concentrations of light rare earth elements (LREE) compared with heavy rare earth elements (HREE) observed in the KIC volcanic rocks suggest that they are similar to arc related rocks (Condie, 2001, 2005; Li et al., 2013; Pearce et al., 1984; Wilson, 2007). In addition, the negative anomalies of $\mathrm{Ta}, \mathrm{Nb}$ and $\mathrm{Ti}$ (TNT) together with relatively high values of $\mathrm{Cs}, \mathrm{Rb}, \mathrm{Ba}$ and $\mathrm{Pb}$ of the KIC volcanics are characteristics of arc-related potassic igneous rocks (Müller et al., 1992; Sun and McDonough, 1989). High average values of $\mathrm{Ba} / \mathrm{Nb}$ and $\mathrm{Rb} / \mathrm{Nb}$ ratios (62.9 and 11.9 respectively) of $\mathrm{KIC}$ volcanic rocks also indicate that these rocks are similar to typical potassic igneous rocks formed at active continental margins (Muller et al., 1997; Sarjoughian et al., 2012). This is explained by the fact that during a subduction, the HFSE tend to remain in the subducted plate, whereas LILE are easily transferred into the mantle wedge (Pearce, 1983; Tatsumi and Eggins, 1995). Fig.10a shows the distribution of KIC volcanic rocks in the field of arc-related setting with fig. 10b suggesting a continental arc setting for these rocks. In the plot of $\mathrm{Zr} / \mathrm{TiO}_{2}$ vs $\mathrm{Ce} / \mathrm{P}_{2} \mathrm{O}_{5}$, which delineates continental arc from post-collisional arc settings, KIC volcanic rocks plot between continental and post-collisional arc settings (Fig.10c). Thus, these 
observations suggest that the KIC volcanics record a suite from active continental arc to post-collisional setting.

\subsection{Tectonic model}

The Late Cretaceous age (110-92 Ma) of emplacement of the KIC volcanics enables us to associate them to potential coeval tectonic activity. Previous studies have suggested that the Rushan Ocean, separating the Southern Pamir from the Central Pamir, may have been subducting southward beneath the Southern Pamir, prior to its late Triassic - early Jurassic closure (Angiolini et al., 2013; Burtman and Molnar, 1993; Robinson, 2015). Since the KIC volcanics were formed after the closure of the Rushan Ocean, we believe that they should not be related to the subduction of the Rushan Ocean. In addition, the Rushan Ocean being relatively narrow (Angiolini et al., 2013; Burtman, 2010; Leven, 1995; Schwab et al., 2004), the subduction of this Ocean was likely accompanied by limited subduction-related magmatism (Robinson, 2015). South of the Southern Pamir, two arcs have been previously proposed to account for mid- and late-Cretaceous magmatism in the Southern Pamir. The mid-Cretaceous (end of early and beginning of late Cretaceous) magmatism has been related to arc-activity following alleged subduction of the Wakhan basin prior to the collision of Karakoram with the Southern Pamir, while the late Cretaceous magmatic activity was suggested to be related to the Neotethys subduction along the Shyok suture (Schwab et al., 2004). The absence of 
evidence for subduction along the Tirich-Wakhan Boundary Zone and the presence of the overprinted Wakhan basin, has been interpreted to represent a sub-continental basin developed along a zone of attenuated continental crust (Zanchi et al., 2000). This subcontinental basin has been interpreted to close in the Jurassic following the collision between Karakoram and the Southern Pamir (Angiolini et al., 2013; Faisal et al., 2014; Robinson, 2015; Zanchi et al., 2000). The evidence for pre-Cretaceous closure of the Wakhan basin is given by the 121 -127 Ma Tirich-Mir granitic pluton that intrudes the Wakhan-TBZ, stitching Karakoram with the Southern Pamir (Faisal et al., 2015, 2014; Zanchi and Gaetani, 2011; Zanchi et al., 2007). Therefore, the late Cretaceous formation of the KIC volcanic rocks with arc-related signatures is not related to the Jurassic closure of the intracontinental Rushan and Wakhan basins. A more likely mechanism is the mid Cretaceous northward subduction of the Shyok (Neotethys) Ocean that initiated south of the Karakoram after the accretion of the Karakoram to the Southern Pamir. A northward flat-dipping slab subduction of the Shyok oceanic crust beneath the relatively thickened Karakoram and the Southern Pamir could account for the generation of the shoshonitic magmas as far north as the location of the KIC volcanics at the end of the early Cretaceous. The closure of the Shyok Ocean occurred during the late Cretaceous, followed by the accretion of the Kohistan Island Arc to the Eurasian margin (Faisal et al., 2014; Fraser et al., 2001). The suturing of the Kohistan Island arc to the South margin of Asia is still controversially dated (90 - $40 \mathrm{Ma}$ ) (Bouilhol et al., 2013; 
Faisal et al., 2014; Fraser et al., 2001; Khan et al., 2009; Robertson and Collins, 2002). These ages suggest that the $92 \mathrm{Ma}$ termination of the KIC volcanic emplacement coincides with the onset of the collision of the Kohistan island arc. This nicely fits with the transitional character of the tectonic setting of the KIC volcanics from continental arc to post-collisional (Fig. 10c) that may reflect the transition from subduction of the Shyok to the collision of Kohistan with the Karakoram. However, a recent study suggested that the Kohistan paleoIsland arc formed in the equatorial part of Neotethys and first collided with India at around $50 \mathrm{Ma}$ and then with Eurasia at around $40 \mathrm{Ma}$ (Bouilhol et al., 2013). In this case, as an alternative interpretation, the transitional character of the tectonic setting of the KIC volcanic rocks may indicate crustal thickening toward the back arc as it was suggested by Muller et al. (1992). Nevertheless, the expected steepening of the Benioff zone following the subduction of the Shyok Oceanic crust and the onset of collision or crustal thickening toward the back-arc might have resulted in the generation of the observed KIC shoshonitic magmas (Fig. 11). Further mixing of both magma components in conjunction with simultaneous open-system fractional crystallization would have occurred in lower crustal levels. The resulting hybrid magma would then have ascended and have tapped into magmatic chambers located in higher crustal levels, where its fractionation continued until its eruption (Fig.11).

As a comparison, voluminous Cretaceous volcanic rocks and plutons are also widespread in the adjacent Qiangtang and Lhasa terranes of the 
Tibetan Plateau, which have been interpreted as products of bilateral subduction of the Bangong Ocean and the collision between Qiangtang and Lhasa terranes (e.g. Chen et al., 2015; Hu et al., 2017; Li et al., 2015; Liu et al., 2015, 2012; Sui et al., 2013). The Qiangtang igneous rocks are high-K calc-alkaline in the south (Hao et al., 2016; Li et al., 2013, 2015; Liu et al., 2015) and shoshonitic in the north (Zhong et al., 2007), while those from northern Lhasa terrane are calcalkaline to High-K calc-alkaline (Chen et al., 2015; Hu et al., 2017; Sui et al., 2013). A coeval magmatic activity is also present in the Karakoram terrane, south of Pamir, which is represented by calc-alkaline to high-K-calc-alkaline Tirich-Mir, Buni-Zom plutons and the Karakoram batholith (Faisal et al., 2015; Ravikant et al., 2009; Zanchi and Gaetani, 2011). These plutonic rocks have been related genetically to the northward subduction of the Shyok Ocean along the southern margin of the Karakoram terrane (e.g. Faisal et al., 2015). These observations suggest 1) that the Southern Pamir KIC volcanic rocks and the Cretaceous plutons in the Karakoram terrane must be the products of a single arc, with the Southern Pamir volcanics being erupted near the back-arc and 2) that the northward subduction of the Shyok Ocean might correlate with the northward subduction of the Bangong Oceanic crust beneath the Qiangtang terrane. Moreover, the closure of the Bangong Ocean, described as diachronous between middle Jurassic in the east and middle Cretaceous in the west (Liu et al., 2014; Wang et al., 2014; Yin and Harrison, 2000), is also consistent with the interpretation that Shyok Ocean, which closed in the early late Cretaceous, is 
correlative with Bangong Ocean in Tibet (Angiolini et al., 2013; Burtman and Samygin, 2001; Robinson, 2015; Robinson et al., 2012).

The shoshonitic magma generation beneath the crust of the Southern Pamir by high-pressure fractional crystallization of mantle derived magmas may imply significant crustal thickening in this region and associated topographic elevation in the late Cretaceous. The flat-dipping slab subduction and suturing events along the Shyok suture would imply additional shortening and thickening from 110 to 90 Ma from the Kohistan arc to the Southern Pamir and possibly further north. This supports previous evidence for significant crustal shortening, thickening and metamorphism during the early to late Cretaceous throughout the Cimmerian terranes forming the Pamir (Fraser et al., 2001, Hildebrand et al., 2001 and Streule et al., 2009; Robinson et al., 2004; 2007; 2015). This suggests that an extensive Pamir plateau was already largely formed by late Cretaceous. This plateau would have constituted, with the alleged pre-Cenozoic "Lhasa-plano" of the Tibetan plateau, a major topographic feature with potentially important implications for atmospheric circulation such as the monsoonal circulation that may have been present at this time (Huber and Armstrong, 2012).

Our model also supports the interpretation of Robinson, (2015) that a significant part of the crustal shortening and thickening accommodated in the Pamir may have occurred in the Mesozoic before the India-Asia collision. PostCimmerian crustal shortening can be currently estimated to about $240 \mathrm{~km}$ 
(Stubner et al., 2013). Our results indicate that some of this shortening must be accounted for by pre-collisional shortening within the Cimmerian terranes. This has important implications for the geodynamic reconstructions of convergence estimates (van Hinsbergen et al., 2011) and their relations to subduction processes using tomographic data (Negredo et al., 2007; Capitanio and Replumaz, 2013).

In effect, this reduces the Pamir shortening budget during and after the India-Asia collision. This therefore implies less deformation of the Asian upper lithospheric plate to account for proposed associated processes such as delamination or continental subduction (e.g. Kufner et al., 2016; Sobel et al., 2014; Replumaz et al., 2016) and more generally the transfer of deformation on major lithospheric strike-slip structures (e.g. Karakoram and Chaman faults; van Hinsbergen et al., 2011). 


\section{Conclusions}

The KIC volcanics representing a range of intermediate to acidic rocks, which exhibit High-K calc-alkaline and shoshonitic affinity and show arc related trace element signatures, were erupted in the Albian-Turonian time (91.8 \pm 1.9 - 109.6 $\pm 1.7 \mathrm{Ma}$; early-late Cretaceous). These volcanics were derived from crustal under- or intra-plating of mantle magmas from enriched subduction-modified lithosphere, by heating and partial melting of the lower crust, and by mixing of both magma components followed by open-system fractional crystallization. Silicic members of the volcanic rocks were derived by fractionation of hybrid magma in the magma chambers located in higher crustal levels.

The shoshonitic magmas of the KIC volcanic rocks have been most likely derived by subduction of Shyok Oceanic crust beneath the Karakoram and the Southern Pamir in a continental arc tectonic setting. Potassium enrichment during the span of the KIC emplacement (110-92 Ma) indicates coeval steepening of the Benioff zone that is related to the collision of the Kohistan arc. The transitional character of the tectonic setting of the volcanics between continental arc and post-collisional setting may reflect the subduction collision transition along the Shyok suture due to accretion of the Kohistan island arc to the Karakoram. Alternatively, this transition might be related to crustal thickening toward the back arc. 
Our results support that much of the shortening and thickening of the Pamir crust might have occurred before the India-Asia collision. We thus suggest that an extensive Pamir plateau already largely formed by late Cretaceous implying monsoonal circulation may have been nascent at this time. 


\section{Acknowledgements}

We are grateful to the Associate Editor Dr, Inna Safonova and Editor-in-Chief Professor Santosh for handling this manuscript. We are also grateful to Dr. Stephane Guillot, Dr. Dmitry Konopelko and Dr. Alexander Robinson for their insightful review that greatly improved the manuscript. We thank Dr. Liu Deliang at ITPCAS, professor Vlasov Nikita Georgievich at the Russian Geological Research Institute for their constructive comments on an early draft of this manuscript. We thank Prof. Sun Yali, Dr. Yue Yahui and Dr. Xie Jing at ITPCAS and Dr. Ren Minghao at Guangzhou Institute of Geochemistry for their assistance with $\mathrm{U}-\mathrm{Pb}$ dating, major element, trace element, isotopic and electron microprobe analysis. This work was supported by NSF of China (No. 41490610 to Ding) and the program (B) of Chinese Academy of Sciences (XDB03010401 to Ding). G. D-N acknowledges support from ERC "MAGIC", ANR "DSP-Tibet" and Cai Yuanpei programme from the French Ministry of Foreign Affairs. 


\section{Figures:}

Fig. 1 Simplified tectonic map of the Pamir, modified after Angiolini et al. (2013); Burtman and Molnar (1993); Robinson (2014); Shvol'man (1977); Schwab et al. (2004);

Fig. 2 a) Geological map of the Kyzylrabat area; b) geological map of the Teshiktash sequence; c) geological map of the Beik sequence. Symbols on the maps indicate samples collected from different formations (square - Ganjibay; circle - Julbeles; triangle - Tashbulak). The symbols with the same shape are used in all the diagrams of this paper.

Fig. 3 a) Field photograph of a contact of volcanic rocks with conglomerates; bd) photographs of hand specimens from the Ganjibay, Julbeles and Tashbulak formations respectively; e-m) photomicrographs of rock samples: e-h) Ganjibay formation - dacite; i-j) Julbeles formation - dacite and Q-latite respectively; k-l) Tashbulak formation - latite and dacite respectively; $m$ ) resorbed phenocryst of quartz in rhyolite. Amp amphibole; Bt - biotite; Chl - chlorite; Cpx - clinopyroxene; Kfs - Kfeldspar; Pl - plagioclase; Qz - quartz.

Tashbulak formation - latite and quartz latite respectively

Fig. 4 a) Total alkali versus $\mathrm{SiO}_{2}$ (TAS) diagram for the KIC volcanic rocks, as proposed by Le Bas et al. (1986) and codified by Le Maitre et al. (1989). Dividing line between alkaline and subalkaline series is that of Irvine and 
Baragar (1971); b) $\mathrm{SiO}_{2}$ vs. $\mathrm{K}_{2} \mathrm{O}$ diagram proposed by Peccerillo and Taylor (1976) to distinguish between tholeiitic, calc-alkaline and shoshonitic rock series.

Fig. 5 a-c) Primitive mantle-normalized trace element patterns for the KIC volcanic rocks: a) Ganjibay formation; b) Julbeles formation; c) Tashbulak formation. The primitive mantle normalization values are from Mcdonough and Sun (1995); d-f) chondrite-normalized REE patterns for the KIC volcanic rocks: d) Ganjibay formation; e) Julbeles formation; f) Tashbulak formation. Chondrite values are from Boynton (1984);

Fig. $6 \varepsilon \mathrm{Nd}(\mathrm{t}) \mathrm{vs}{ }^{87} \mathrm{Sr}^{86} \mathrm{Sr}_{(\mathrm{i})}$ for the KIC volcanic rocks. Mixing lines between depleted mantle and High Himalayan Crystalline Rocks (HHC) and that between depleted mantle and lower crust are based on data given by Ding et al. (2003) and Othman et al., (1984) respectively.

Fig. 7 a) Chemical composition of feldspars from the KIC volcanic rocks plotted on the An-Ab-Or ternary diagram; b) clinopyroxene Wo-En-Fs classification diagram; c-d) classification diagram for amphiboles (Hawthorne and Oberti, 2007; Leake et al., 1997); e) Composition of biotites from the KIC volcanics; $\mathrm{f}) \mathrm{Fe}^{2+} /\left(\mathrm{Fe}^{2+}+\mathrm{Mg}\right)$ vs $\mathrm{Al}^{\mathrm{IV}}$ diagram of biotites (Jiang et al., 2002).

Fig. 8 a) $\mathrm{MgO}$ vs $\mathrm{SiO}_{2}$; b) $\mathrm{Fe}_{2} \mathrm{O}_{3}$ vs $\mathrm{MgO}$; c) $\mathrm{Cr}$ vs $\mathrm{MgO}$; d) $\mathrm{CaO}$ vs $\mathrm{SiO}_{2}$; e) $\mathrm{La} / \mathrm{Tb}$ vs $\mathrm{SiO}_{2}$; f) $\mathrm{Zr} / \mathrm{Sm}$ vs $\mathrm{SiO}_{2}$; g) La/Yb vs $\mathrm{La}$; h) $\mathrm{La} / \mathrm{Sm}$ vs $\mathrm{La}$; i) $\mathrm{Rb}$ 
vs $\mathrm{Ba}$ diagrams. a-c: fractional crystallization of mafic minerals; d-f: fractional crystallization of plagioclase, clinopyroxene and amphibole; g: the KIC volcanic rocks show linear trend on $\mathrm{La} / \mathrm{Yb}$ vs $\mathrm{La}$ diagram indicating partial melting of the source material; $h$ ) arcuate trend indicating magma mixing; $\mathrm{i}: \mathrm{Rb}$ vs $\mathrm{Ba}$ vector diagram showing inferred fractional crystallization trends for the KIC volcanic rocks. The partition coefficients for $\mathrm{Rb}$ and $\mathrm{Ba}$ are from Rollinson (1993) and the vectors were calculated from Rayleigh fractionation equation. Pl - plagioclase; Cpx - clinopyroxene; Amp - amphibole; Kfs - potassium feldspar; Bt biotite. The schematic diagrams from Schiano et al. (2010) are also indicated, in which $\mathrm{CH}, \mathrm{CM}, \mathrm{C} 0$ and $\mathrm{DM}$ are the concentrations of highly incompatible elements $(\mathrm{H})$, moderately incompatible elements $(\mathrm{M})$, the corresponding primary source materials (0) and the bulk solid/melt partition coefficient of an element M respectively.

Fig. 9 Zircon $\mathrm{U}-\mathrm{Pb}$ ages vs in situ $\varepsilon \mathrm{Hf}(\mathrm{t})$ values.

Fig. 10 Tectonic setting discrimination diagrams of KIC volcanic rocks, showing arc-related tectonic setting for these rocks - a) $\mathrm{Zr} / \mathrm{Al}_{2} \mathrm{O}_{3}$ vs $\mathrm{TiO}_{2} / \mathrm{Al}_{2} \mathrm{O}_{3} ;$ b) $\mathrm{La} / \mathrm{Yb}$ vs $\mathrm{Th} / \mathrm{Yb}$ (Condie, 1989) and c) $\mathrm{Ce} / \mathrm{P}_{2} \mathrm{O}_{5}$ vs $\mathrm{Zr} / \mathrm{TiO}_{2}$ (Muller et al., 1997).

Fig. 11 The tectonic model for the generation of KIC magmas. The shoshonitic magmas are generated by the subduction of the Shyok Ocean beneath the 
Karakoram - Southern Pamir region. The shoshonitic magmas are related to steepening of the Benioff zone during subduction. RPS - RushanPshart Suture; W-TBZ - Wakhan-Tirich Boundary Zone. 


\section{References}

Afonichev, N., Vlasov, N., 1984. Geological map of Kazakhstan and Central Asia M1:1 500 000, attachments.

Allegre, C., Minster, J., 1978. Quantitative models of trace element behavior in magmatic processes. Earth and Planetary Science Letters 38, 1-25.

Angiolini, L., Zanchi, A., Zanchetta, S., Nicora, A., Vezzoli, G., 2013. The Cimmerian geopuzzle: new data from South Pamir. Terra Nova 25, 352360.

Angiolini, L., Zanchi, A., Zanchetta, S., Nicora, A., Vuolo, I., Berra, F., Henderson, C., Malaspina, N., Rettori, R., Vachard, D., 2014. From rift to drift in South Pamir (Tajikistan): Permian evolution of a Cimmerian terrane. Journal of Asian Earth Sciences. doi:10.1016/j.jseaes.2014.08.001.

Arnaud, N., Vidal, P., Tapponnier, P., Matte, P., Deng, W., 1992. The high $\mathrm{K}_{2} \mathrm{O}$ volcanism of northwestern Tibet: Geochemistry and tectonic implications. Earth and Planetary Science Letters 111, 351-367.

Bacon, C.R., Druitt, T.H., 1988. Compositional evolution of the zoned calcalkaline magma chamber of Mount Mazama, Crater Lake, Oregon. Contributions to Mineralogy and Petrology 98, 224-256. 
Bosboom, R., Mandic, O., Dupont-Nivet, G., Proust, J.-N., Ormukov, C., \& Aminov, J. 2015. Late Eocene palaeogeography of the proto-Paratethys Sea in Central Asia (NW China, southern Kyrgyzstan and SW Tajikistan). Geological Society, London, Special Publications. http://doi.org/10.1144/SP427.11

Bouilhol, P., Jagoutz, O., Hanchar, J.M., Dudas, F.O., 2013. Dating the IndiaEurasia collision through arc magmatic records. Earth and Planetary Science Letters 366, 163-175. doi:10.1016/j.eps1.2013.01.023.

Boynton, W.V., 1984. Cosmochemistry of the rare-earth elements: meteorite studies, in: Henderson, P. (Ed.), Rare Earth Element Geochemistry. Elsevier, Amsterdam, pp. 63-114.

Budanov, V., 1964. The main features of the history of magmatism in the Pamirs, in:The materials on the geology of Pamir. pp. 174-194.

Budanov, V.I., Volkova, N.I., Dronov, V.I., 1999. Petrochemistry of rhyodacitetrachyte series in a paleogene volcanoplutonic belt in the Southeastern Pamirs. Geologiya I Geofizika 40, 667-673.

Burtman, V., Samygin, S., 2001. Tectonic evolution of High Asia in the Paleozoic and Mesozoic. Geotectonics 35, 276-294.

Burtman, V.S., 1994. Meso-Tethyan Oceanic Sutures and Their Deformation. Tectonophysics 234, 305-327. 
Burtman, V.S., 2010. Tien Shan, Pamir, and Tibet: History and geodynamics of phanerozoic oceanic basins. Geotectonics 44, 388-404.

Burtman, V.S., Molnar, P., 1993. Geological and geophysical evidence for deep subduction of continental crust beneath the Pamir. Geological Society of America Special Papers 281, 1-76.

Campbell, I.H., Stepanov, A.S., Liang, H.-Y., Allen, C.M., Norman, M.D., Zhang, Y.-Q., Xie, Y.-W., 2014. The origin of shoshonites: new insights from the Tertiary high-potassium intrusions of eastern Tibet. Contributions to Mineralogy and Petrology 167, 1-22.

Capitanio, F.A. and Replumaz, A., 2013. Subduction and slab breakoff controls on Asian indentation tectonics and Himalayan western syntaxis formation. Geochemistry, Geophysics, Geosystems, 14(9), 3515-3531.

Chen, S.-S., Shi, R.-D., Gong, X.-H., Liu, D.-L., Huang, Q.-S., Yi, G.-D., Wu, K., Zou, H.-B., 2015. A syn-collisional model for Early Cretaceous magmatism in the northern and central Lhasa subterranes. Gondwana Research. doi: 10.1016/j.gr.2015.04.008.

Condie, K.C., 1989. Geochemical changes in basalts and andesites across the Archean-Proterozoic boundary: Identification and significance. Lithos 23, $1-18$.

Condie, K.C., 2001. Mantle plumes and their record in Earth history. Cambridge University Press, Cambridge. 
Condie, K.C., 2005. High field strength element ratios in Archean basalts: a window to evolving sources of mantle plumes? Lithos 79, 491-504.

Cowgill, E., 2010. Cenozoic right-slip faulting along the eastern margin of the Pamir salient, northwestern China. Geological Society of America Bulletin 122, 145-161. doi:10.1130/B26520.1.

Deng, W., 1998. Cenozoic intraplate volcanic rocks in the northern QinghaiXizang plateau. Geological Publishing House, Beijing.

Ding, L., Kapp, P., Zhong, D., Deng, W., 2003. Cenozoic volcanism in Tibet: evidence for a transition from oceanic to continental subduction. Journal of Petrology 44, 1833-1865.

Douce, A.E.P., 1999. What do experiments tell us about the relative contributions of crust and mantle to the origin of granitic magmas? Geological Society, London, Special Publications 168, 55-75.

Dronov, V., 2003. Stratigraphy and tectonic setting of upper cretaceous rocks in the southeastern part of the Central Pamirs (southern slope of the Muzkol range). Doklady Akademii Nauk 4, 506-508.

Dronov, V., Bronnikova, A., 1988. Stratigraphy and age of Teshiktash volcanic series in the Kyzylrabat district (SE Pamir). Doklady of Academy of Sciences of Tajikistan 31, 54-57. 
Dufour, M., Dronov, V., Kushlin, B., 1958. The stratigraphy of the Triassic in the South-Eastern Pamirs. Doklady Akademii Nauk SSSR 123, 523-525.

Edgar, A.D., Arima, M., 1985. Fluorine and chlorine contents of phlogopites crystallized from ultrapotassic rock compositions in high pressure experiments; implication for halogen reservoirs in source regions. American Mineralogist 70, 529-536.

Faisal, S., Larson, K.P., Cottle, J.M., Lamming, J., 2014. Building the Hindu Kush: monazite records of terrane accretion, plutonism and the evolution of the Himalaya-Karakoram-Tibet orogen. Terra Nova 26, 395-401.

Faisal, S., Larson, K.P., King, J., Cottle, J.M., 2015. Rifting, subduction and collisional records from pluton petrogenesis and geochronology in the Hindu Kush, NW Pakistan. Gondwana Research. doi: 10.1016/j.gr.2015.05.014.

Foley, S., Peccerillo, A., 1992. Potassic and ultrapotassic magmas and their origin. Lithos 28, 181-185.

Fraser, J.E., Searle, M.P., Parrish, R.R., Noble, S.R., 2001. Chronology of deformation, metamorphism, and magmatism in the southern Karakoram Mountains. Geological Society of America Bulletin 113, 1443-1455.

Gaetani, M., 1997. The Karakoram block in central Asia, from Ordovician to Cretaceous. Sedimentary Geology 109, 339-359. 
Gaetani, M., Angiolini, L., Nicora, A., Sciunnach, D., Le Fort, P., Tanoli, S., Khan, A., 1996. Reconnaissance geology in upper Chitral, Baroghil and Karambar districts (northern Karakoram, Pakistan). Geologische Rundschau 85, 683-704.

Gurnis, M., 1992. Rapid continental subsidence following the initiation and evolution of subduction. Science 255(5051), 1556.

Hao, L.L., Wang, Q., Wyman, D.A., Ou, Q., Dan, W., Jiang, Z.Q., Wu, F.Y., Yang, J.H., Long, X.P., Li, J., 2016. Underplating of basaltic magmas and crustal growth in a continental arc: Evidence from Late Mesozoic intermediate-felsic intrusive rocks in southern Qiangtang, central Tibet. Lithos 245, 223-242. doi:10.1016/j.lithos.2015.09.015

Hawthorne, F.C., Oberti, R., 2007. Classification of the amphiboles. Reviews in Mineralogy and Geochemistry 67, 55-88.

Hermann, J., Spandler, C.J., 2008. Sediment melts at sub-arc depths: An experimental study. Journal of Petrology 49, 717-740.

Heuberger, S., Schaltegger, U., Burg, J.-P., Villa, I.M., Frank, M., Dawood, H., Hussain, S., Zanchi, A., 2007. Age and isotopic constraints on magmatism along the Karakoram-Kohistan Suture Zone, NW Pakistan: evidence for subduction and continued convergence after India-Asia collision. Swiss Journal of Geosciences 100, 85-107. doi:10.1007/s00015-007-1203-7 
Hildebrand, P.R.R., Noble, S.R.R., Searle, M.P.P., Waters, D.J.J., Parrish, R.R.R., 2001. Old origin for an active mountain range: Geology and geochronology of the eastern Hindu Kush, Pakistan. Geological Society of America Bulletin 113, 625-639.

Hu, X.-C., Xia, B., Huang, Q.-T., Liu, W.-L., Zhong, Y., Yuan, Y.-J., Xia, L.-Z., Wu, Y., Zhang, X., 2017. Geochemistry, geochronology, and petrogenesis of mid-Cretaceous Talabuco volcanic rocks, central Tibet: implications for the evolution of the Bangong Meso-Tethys. International Geology Review 59, 484-501. doi:10.1080/00206814.2016.1230524

Huber, M. and Goldner, A., 2012. Eocene monsoons. Journal of Asian Earth Sciences 44, 3-23.

Husson, L., 2006. Dynamic topography above retreating subduction zones. Geology, 34(9), 741-744.

Hoskin, P., Schaltegger, U., 2003. The composition of zircon and igneous and metamorphic petrogenesis. Reviews in Mineralogy and Geochemistry 1, $27-62$.

Ivanova, T.P., Trifonov, V.G., 2005. Neotectonics and mantle earthquakes in the Pamir-Hindu Kush region. Geotectonics 39, 56-68.

Irvine, T., Baragar, W., 1971. A guide to the chemical classification of the common volcanic rocks. Canadian journal of earth sciences 8, 523-548. 
Jiang, Y.-H., Jiang, S.-Y., Ling, H.-F., Zhou, X.-R., Rui, X.-J., Yang, W.-Z., 2002. Petrology and geochemistry of shoshonitic plutons from the western Kunlun orogenic belt, Xinjiang, northwestern China: implications for granitoid geneses. Lithos 63, 165-187.

Joplin, G.A., 1968. The shoshonite association: A review. Journal of the Geological Society of Australia 15, 275-294.

Khan, S. D., Walker, D.J., Hall, S.A., Burke, K.C., Shah, M.T., and Stockli, L., 2009. Did the Kohistan-Ladakh island arc collide first with India? Bulletin of the Geological Society of America 121(3-4), 366-384. doi:10.1130/B26348.1.

Kufner, S.K., Schurr, B., Sippl, C., Yuan, X., Ratschbacher, L., Ischuk, A., Murodkulov, S., Schneider, F., Mechie, J., Tilmann, F., 2016. Deep India meets deep Asia: Lithospheric indentation, delamination and break-off under Pamir and Hindu Kush (Central Asia). Earth and Planetary Science Letters 435, 171-184.

Küster, D., Harms, U., 1998. Post-collisional potassic granitoids from the southern and northwestern parts of the Late Neoproterozoic East African Orogen: A review. Lithos 45, 177-195.

Le Bas, M., Le Maitre, R., Streckeisen, A., Zanettin, B., 1986. A chemical classification of volcanic rocks based on the total alkali-silica diagram. Journal of Petrology 27, 745-750. 
Le Maitre, R.W., Bateman, P., Dudek, A., Keller, J., Lameyre, J., Le Bas, M., Sabine, P., Schmid, R., Sorensen, H., Streckeisen, A., 1989. A classification of igneous rocks and glossary of terms: Recommendations of the International Union of Geological Sciences Subcommission on the Systematics of Igneous Rocks. Blackwell Oxford. 193 pp.

Leven, E.J., 1995. Permian and Triassic of the Rushan-Pshart zone (Pamir). Rivista Italiana di Paleontologia e Stratigrafia 101, 3-16.

Li, Y., He, J., Wang, C., Santosh, M., Dai, J., Zhang, Y., Wei, Y., Wang, J., 2013. Late Cretaceous K-rich magmatism in central Tibet: Evidence for early elevation of the Tibetan plateau? Lithos 160-161, 1-13.

Li, Y., He, J., Wang, C., Han, Z., Ma, P., Xu, M., Du, K., 2015. Cretaceous volcanic rocks in south Qiangtang Terrane: Products of northward subduction of the Bangong-Nujiang Ocean? Journal of Asian Earth Sciences 104, 69-83. doi:10.1016/j.jseaes.2014.09.033

Liu, D., Shi, R., Ding, L., Huang, Q., Zhang, X., Yue, Y., Zhang, L., 2015. Zircon $\mathrm{U}-\mathrm{Pb}$ age and $\mathrm{Hf}$ isotopic compositions of Mesozoic granitoids in southern Qiangtang, Tibet: Implications for the subduction of the Bangong-Nujiang Tethyan Ocean. Gondwana Research. doi:10.1016/j.gr.2015.04.007

Liu, S., Hu, R., Gao, S., Feng, C., Coulson, I.M., Feng, G., Qi, Y., Yang, Y., Yang, C., Tang, L., 2012. U-Pb zircon age, geochemical and Sr-Nd 
isotopic data as constraints on the petrogenesis and emplacement time of andesites from Gerze, southern Qiangtang Block, northern Tibet. Journal of Asian Earth Sciences 45, 150-161. doi:10.1016/j.jseaes.2011.09.025

Ludwig, K., 2012. Isoplot/Ex, v. 3.75. Berkeley Geochronology Center Special Publication.

Mahéo, G., Blichert-Toft, J., Pin, C., Guillot, S., Pêcher, A., 2009. Partial melting of mantle and crustal sources beneath South Karakorum, Pakistan: implications for the Miocene geodynamic evolution of the India-Asia convergence zone. Journal of Petrology 50, 427-449.

Mcdonough, W.F., Sun, S.S., 1995. The Composition of the Earth. Chemical Geology 120, 223-253.

Meen, J.K., 1987. Formation of shoshonites from calcalkaline basalt magmas: geochemical and experimental constraints from the type locality. Contributions to Mineralogy and Petrology 97, 333-351.

Meskhi, A., 1964. Magmatic complexes of the south-eastern Pamir, in: The materials on the geology of the Pamir. pp. 195-213.

Meskhi, A., 1974. Petrology of Aksu monzonitoid volcano-pluton. Abstract of the $\mathrm{PhD}$ thesis, 24.

Miller, C., Schuster, R., Klötzli, U., Frank, W., Purtscheller, F., 1999. Postcollisional potassic and ultrapotassic magmatism in SW Tibet: 
geochemical and $\mathrm{Sr}-\mathrm{Nd}-\mathrm{Pb}-\mathrm{O}$ isotopic constraints for mantle source characteristics and petrogenesis. Journal of Petrology 40, 1399-1424.

Miller, C., Schuster, R., Klotzli, U., Frank, W., Grasemann, B., 2000. Late Cretaceous-Tertiary magmatic and tectonic events in the Transhimalaya batholith (Kailas area, SW Tibet). Schweizerische Mineralogische und Petrographische Mitteilungen 80, 1-20.

Morrison, G.W., 1980. Characteristics and Tectonic Setting of the Shoshonite Rock Association. Lithos 13, 97-108.

Müller, D.-G.D., Rock, N., Groves, D., 1992. Geochemical discrimination between shoshonitic and potassic volcanic rocks in different tectonic settings: a pilot study. Mineralogy and Petrology 46, 259-289.

Muller, D., Groves, D.I., Titley, S.R., 1997. Potassic igneous rocks and associated gold-copper mineralization. Economic Geology and the Bulletin of the Society of Economic Geologists 92, 505.

Nachit, H., Ibhi, A., Abia, E.H., Ohoud, M.B., 2005. Discrimination between primary magmatic biotites, reequilibrated biotites and neoformed biotites. Comptes Rendus Geoscience 337, 1415-1420.

Negredo, A.M., Replumaz, A., Villaseñor, A. and Guillot, S., 2007. Modeling the evolution of continental subduction processes in the Pamir-Hindu Kush region. Earth and Planetary Science Letters, 259(1), 212-225. 
Othman, D. Ben, Polvé, M., Allègre, C.J., 1984. Nd-Sr isotopic composition of granulites and constraints on the evolution of the lower continental crust. Nature 307, 510-515. doi:10.1038/307510a0

Pashkov, B., Shvolman, V., 1979. Rift margins of Tethys in the Pamirs. Geotectonics 13, 447-456.

Pashkov, B.R., Budanov, V.I., 1990. Tectonics of the SE-SW Pamir Junction. Geotectonics 24, 246-253.

Pearce, J., 1983. Role of the sub-continental lithosphere in magma genesis at active continental margins. Continental Basalts and Mantle Xenoliths, 230-249.

Pearce, J.A., Harris, N.B., Tindle, A.G., 1984. Trace element discrimination diagrams for the tectonic interpretation of granitic rocks. Journal of Petrology 25, 956-983.

Peccerillo, A., 1990. On the origin of the Italian potassic magmas-comments. Chemical Geology 85, 183-191.

Peccerillo, A., Taylor, S.R., 1976. Geochemistry of Eocene calc-alkaline volcanic rocks from the Kastamonu area, northern Turkey. Contributions to Mineralogy and Petrology 58, 63-81. 
Petterson, M.G., 2010. A review of the geology and tectonics of the Kohistan island arc, north Pakistan. Geological Society, London, Special Publications, 338(1), 287-327.

Puzankov, Y.M., Anoshin, G., Budanov, V., Volynets, O., Melgunov, S., 2000. Meso-Cenozoic collision-accretionary volcanic complexes of the Central and Southern Pamirs (an example of active margin-plume magmatism evolution). Geologia i geofizika (Russian geology and geophysics) 41, 616-632.

Ravikant, V., Wu, F.Y., Ji, W.Q., 2009. Zircon U-Pb and Hf isotopic constraints on petrogenesis of the Cretaceous-Tertiary granites in eastern Karakoram and Ladakh, India. Lithos, 110(1-4), 153-166.

Replumaz, A., Funiciello, F., Reitano, R., Faccenna, C. and Balon, M., 2016. Asian collisional subduction: A key process driving formation of the Tibetan Plateau. Geology, 44(11), 943-946.

Rieder, M., Cavazzini, G., D’yakonov, Y.S., Frank-Kamenetskii, V.A., Gottardi, G., Guggenheim, S., Koval, P.V., Müller, G., Neiva, A.M., Radoslovich, E.W., 1998. Nomenclature of the micas. The Canadian Mineralogist 36, 8-30.

Roberts, M.P., Clemens, J.D., 1993. Origin of high-potassium, calc-alkaline, Itype granitoids. Geology 21, 825-825. 
Robertson, A. H. F., and A. S. Collins (2002), Shyok Suture Zone, N Pakistan:

Late Mesozoic-Tertiary evolution of a critical suture separating the oceanic Ladakh Arc from the Asian continental margin. Journal of Asian Earth Sciences, 20(3), 309-351. doi:10.1016/S1367-9120(01)00041-4.

Robinson, A.C., 2015. Mesozoic tectonics of the Gondwanan terranes of the Pamir plateau. Journal of Asian Earth Sciences, 102, 170-179. doi: 10.1016/j.jseaes.2014.09.012.

Robinson, A.C., Ducea, M., Lapen, T.J., 2012. Detrital zircon and isotopic constraints on the crustal architecture and tectonic evolution of the northeastern Pamir. Tectonics 31. doi: 10.1029/2011TC003013

Rollinson, H.R., 1993. Using geochemical data: evaluation, presentation, interpretation, Routledge. doi:10.1180/minmag.1994.058.392.25

Ruzhentsev, S., Shvol'man, V., 1981. Tectonic zoning of the Pamirs and Afghanistan. Contemporary geoscientific researches in Himalaya: Dehradun Bishan Singh. Mahendra Pal Singh Publishers 1, 53-59.

Sarjoughian, F., Kananian, A., Haschke, M., Ahmadian, J., 2012. Geochemical signature of Eocene Kuh-e Dom shoshonitic dikes in NE Ardestan, Central Iran: implications for melt evolution and tectonic setting. Journal of Geosciences 57, 241-264.

Schiano, P., Monzier, M., Eissen, J.P., Martin, H., Koga, K.T., 2010. Simple mixing as the major control of the evolution of volcanic suites in the 
Ecuadorian Andes. Contributions to Mineralogy and Petrology 160, 297312.

Schmidt, J., Hacker, B.R., Ratschbacher, L., Stübner, K., Stearns, M., KylanderClark, A., Cottle, J.M., Alexander, A., Webb, G., Gehrels, G., Minaev, V., 2011. Cenozoic deep crust in the Pamir. Earth and Planetary Science Letters 312, 411-421.

Schwab, M., Ratschbacher, L., Siebel, W., McWilliams, M., Minaev, V., Lutkov, V., Chen, F., Stanek, K., Nelson, B., Frisch, W., 2004. Assembly of the Pamirs: Age and origin of magmatic belts from the southern Tien Shan to the southern Pamirs and their relation to Tibet. Tectonics 23 (4). doi: 10.1029/2003TC001583.

Searle, M., Rex, A., Tirrul, R., Rex, D., Barnicoat, A., Windley, B., 1989. Metamorphic, magmatic, and tectonic evolution of the central Karakoram in the Biafo-Baltoro-Hushe regions of northern Pakistan. Geological Society of America Special Papers 232, 47-74.

Searle, M.P., Parrish, R.R., Thow, A.V., Noble, S., Phillips, R.J., Waters, D.J., 2010. Anatomy, age and evolution of a collisional mountain belt: the Baltoro granite batholith and Karakoram Metamorphic Complex, Pakistani Karakoram. Journal of the Geological Society, London 167, 183-202. 
Sekine, T., Wyllie, P.J., 1982. Phase relationships in the system $\mathrm{KAlSiO}_{4^{-}}$ $\mathrm{Mg}_{2} \mathrm{SiO}_{4}-\mathrm{SiO}_{2}-\mathrm{H}_{2} \mathrm{O}$ as a model for hybridization between hydrous siliceous melts and peridotite. Contributions to Mineralogy and Petrology 79, 368-374.

Shvol'man, V., 1977. Tectonic Development of the Pamir in the Cretaceous and Paleogene Periods. Transactions of the Geological Institute, Akademiya Nauk USSR 302, 160.

Shvolman, V., 1978. Relicts of the Mesotethys in the Pamirs. Himalayan Geology 8, 369-378.

Shvolman, V., 1980. A mesozoic ophiolite complex in the Pamirs. Geotectonics $14,465-470$.

Streule, M.J., Phillips, R.J., Searle, M.P., Waters, D.J., Horstwood, M.S.A., 2009. Evolution and chronology of the Pangong Metamorphic Complex adjacent to the Karakoram Fault, Ladakh: constraints from thermobarometry, metamorphic modelling and $\mathrm{U}-\mathrm{Pb}$ geochronology. Journal of the Geological Society, London 166, 919-932. http:// dx.doi.org/10.1144/0016-76492008-117.

Stubner, K., Ratschbacher, L., Rutte, D., Stanek, K., Minaev, V., Wiesinger, M., Gloaguen, R., 2013a. The giant Shakhdara migmatitic gneiss dome, Pamir, India- Asia collision zone: 1. Geometry and kinematics. Tectonics $32,948-979$. 
Stubner, K., Ratschbacher, L., Weise, C., Chow, J., Hofmann, J., Khan, J., Rutte, D., Sperner, B., Pfander, J.A., Hacker, B.R., Dunkl, I., Tichomirowa, M., Stearns, M.A., Members, P.T., 2013b. The giant Shakhdara migmatitic gneiss dome, Pamir, India-Asia collision zone: 2. Timing of dome formation. Tectonics 32, 1404-1431.

Sui, Q.L., Wang, Q., Zhu, D.C., Zhao, Z.D., Chen, Y., Santosh, M., Hu, Z.C., Yuan, H.L., Mo, X.X., 2013. Compositional diversity of ca. 110Ma magmatism in the northern Lhasa Terrane, Tibet: Implications for the magmatic origin and crustal growth in a continent-continent collision zone. Lithos 168-169, 144-159. doi:10.1016/j.lithos.2013.01.012

Sun, S.-S., McDonough, W., 1989. Chemical and isotopic systematics of oceanic basalts: implications for mantle composition and processes. Geological Society, London, Special Publications 42, 313-345.

Tatsumi, Y., Eggins, S., 1995. Subduction zone magmatism. Vol. 1, Wiley.

Titov, A., Vladimirov, A., Kruk, N., Palessky, S., 1996. Petrogenesis and age of volcanic rocks from Kyzylrabat structure (South-East Pamir). Geologiya i Geofizika (Russian Geology and Geophysics) 37, 62-72.

Turner, S., Arnaud, N., Liu, J., Rogers, N., Hawkesworth, C., Harris, N., Kelley, S., VanCalsteren, P., Deng, W., 1996. Post-collision, shoshonitic volcanism on the Tibetan plateau: Implications for convective thinning of 
the lithosphere and the source of ocean island basalts. Journal of Petrology 37, 45-71.

Van Hinsbergen, D. J. J., Steinberger, B., Doubrovine, P. V., \& Gassmöller, R., 2011. Acceleration and deceleration of India-Asia convergence since the Cretaceous: Roles of mantle plumes and continental collision. Journal of Geophysical Research: Solid Earth, 116(6), 1-20. http://doi.org/10.1029/2010JB008051

Van Hinsbergen, D.J., Kapp, P., Dupont- Nivet, G., Lippert, P.C., DeCelles, P.G. and Torsvik, T.H., 2011. Restoration of Cenozoic deformation in Asia and the size of Greater India. Tectonics, 30(5). http://dx.doi.org/10.1029/2011TC002908

Van Hinsbergen, D. J. J., Lippert, P. C., Dupont-Nivet, G., McQuarrie, N., Doubrovine, P. V., Spakman, W., \& Torsvik, T. H., 2012. Greater India Basin hypothesis and a two-stage Cenozoic collision between India and Asia. Proceedings of the National Academy of Sciences, 109(20), 76597664. http://doi.org/10.1073/pnas.1117262109

Vladimirov, A.G., Belyaeva, R.T., Ponomarchuk, V.A., 1990. Late Mesozoic magmatism of South Pamir, in: Granitic magmatism and mineralization of Bazardara mining district (South-East Pamir). Institute of Geology and Geophysics of Siberian branch of the Russian Academy of Sciences, Novosibirsk, pp. 19-69. 
Vladimirov, A.G., Malykh, M.M., Dronov, V.I., Cherner, E.S., Polyakov, G.V., 1992. Indo-Sinian magmatism and geodynamics of the South Pamirs. IGM SB RAS, Novosibirsk, 228 pp.

Vlasov, N., Dyakov, Y.A., Cherev, E., 1991. Geological map of the Tajik SSR and adjacent territories, 1: 500,000. Leningrad: VSEGEI.

Wilson, B.M., 2007. Igneous petrogenesis a global tectonic approach. Springer Science \& Business Media.

Wu, Z.,. Barosh, P. J., Ye, P., and Hu D., 2015. Late Cretaceous tectonic framework of the Tibetan Plateau, Journal of Asian Earth Sciences, 114, 693-703. doi:10.1016/j.jseaes.2014.11.021.

Yin, A., Harrison, T., Ryerson, F., 1995. Transtension along the left-slip Altyn Tagh and Kunlun faults as a mechanism for the occurrence of Late Cenozoic volcanism in the northern Tibetan Plateau. EOS 76, 567.

Yin, A., Harrison, T.M., 2000. Geologic evolution of the Himalayan-Tibetan orogen. Annual Review of Earth and Planetary Sciences 28, 211-280.

Zanchi, A., Poli, S., Fumagalli, P., Gaetani, M., 2000. Mantle exhumation along the Tirich Mir Fault Zone, NW Pakistan: pre-mid-Cretaceous accretion of the Karakoram terrane to the Asian margin. Geological Society, London, Special Publications 170, 237-252. doi:10.1144/GSL.SP.2000.170.01.13. 
Zanchi, A., Gaetani, M., 2011. The geology of the Karakoram range, Pakistan: the new 1:100,000 geological map of Central-Western Karakoram. Italian Journal of Geosciences 130, 161-262. doi:10.3301/IJG.2011.09.

Zhong, H.M., Xia, J., Qiu, J.Q., Tong, J.S., Lu, R.K., 2007. Discovery of an Early Cretaceous shoshonitic pluton in Yinligou, northwestern Qiangtang, Tibet, China - evidence from geochemical data and zircon $\mathrm{U}-\mathrm{Pb}$ ages. Geological bulletin of China 26, 427-432. 


\section{Tables:}

Table 1 Phenocryst and groundmass mineralogy, U-Pb ages and $\varepsilon H f(t)$ values of the KIC volcanic rocks from the Southern Pamir

\begin{tabular}{|c|c|c|c|c|c|c|}
\hline Sample & Lithology & Phenocrysts & Groundmass & Age & MSWD & $\varepsilon \mathrm{Hf}(\mathrm{t})$ \\
\hline \multicolumn{7}{|c|}{ Tashbulak formation } \\
\hline BK1.1 & Latite & $\mathrm{Pl}+\mathrm{Cpx}$ & $\mathrm{Pl}+\mathrm{Cpx}+\mathrm{Qz}+$ glass & $91.8 \pm 1.9$ & 0.34 & -23.9 to -5.7 \\
\hline BK4.1 & Latite & $\mathrm{Pl}+\mathrm{Cpx}+\mathrm{Amp}+\mathrm{Kfs}$ & $\mathrm{Pl}+\mathrm{Cpx}+\mathrm{Bt}+$ glass & & & \\
\hline BK8.1 & Q-Latite & $\mathrm{Pl}+\mathrm{Cpx}$ & $\mathrm{Pl}+\mathrm{Cpx}+$ glass & & & \\
\hline BK9.2 & Q-Latite & $\mathrm{Pl}+\mathrm{Cpx}$ & $\mathrm{Pl}+\mathrm{Cpx}+\mathrm{Mt}+$ glass & & & \\
\hline BK4.2 & Q-Latite & $\mathrm{Pl}+\mathrm{Kfs}+\mathrm{Cpx}$ & $\mathrm{Pl}+\mathrm{Cpx}+\mathrm{Mt}+\mathrm{Ap}+$ glass & & & \\
\hline TR84 & Dacite & $\mathrm{Pl}+\mathrm{Bt}+\mathrm{Amp}+\mathrm{Opx}$ & $\mathrm{Pl}+\mathrm{Bt}+\mathrm{Qz}+$ glass & $93.1 \pm 2.6$ & 1.15 & \\
\hline BK6.5 & Dacite & $\mathrm{Pl}+\mathrm{Bt}+\mathrm{Amp}+\mathrm{Qz}$ & $\mathrm{Pl}+\mathrm{Bt}+\mathrm{Cpx}+\mathrm{Qz}+$ glass & $94.1 \pm 1.4$ & 2.4 & \\
\hline BK1.3 & Dacite & $\mathrm{Pl}+\mathrm{Bt}+\mathrm{Amp}+\mathrm{Qz}+\mathrm{Cpx}$ & $\mathrm{Pl}+\mathrm{Qz}+\mathrm{Bt}+$ glass & $94.4 \pm 1.2$ & 1.5 & -13.9 to -8.5 \\
\hline TR85 & Dacite & $\mathrm{Pl}+\mathrm{Bt}+\mathrm{Amp}+\mathrm{Cpx}$ & $\mathrm{Pl}+\mathrm{Bt}+\mathrm{Qz}+$ glass & $96.5 \pm 1.9$ & 4.2 & \\
\hline BK3.1 & Rhyolite & $\mathrm{Pl}+\mathrm{Kfs}+\mathrm{Cpx}$ & $\mathrm{Pl}+\mathrm{Cpx}+\mathrm{Qz}+$ glass & $95.1 \pm 1.1$ & 0.53 & -12.0 to -7.2 \\
\hline BK3.2 & Rhyolite & $\mathrm{Pl}+\mathrm{Kfs}+\mathrm{Cpx}$ & $\mathrm{Pl}+\mathrm{Cpx}+\mathrm{Qz}+$ glass & & & \\
\hline \multicolumn{7}{|c|}{ Julbeles formation } \\
\hline BK5.4 & $\begin{array}{l}\text { Basaltic } \\
\text { andesite }\end{array}$ & $\mathrm{Kfs}+\mathrm{Pl}+\mathrm{Amp}+\mathrm{Cpx}$ & $\mathrm{Pl}+\mathrm{Cpx}+\mathrm{Qz}+$ glass & $96.9 \pm 1.0$ & 0.37 & -24.8 to -4.6 \\
\hline BK5.5 & $\begin{array}{l}\text { Basaltic } \\
\text { andesite }\end{array}$ & & & & & \\
\hline DZH002 & Latite & $\mathrm{Pl}+\mathrm{Cpx}+\mathrm{Bt}$ & $\mathrm{Pl}+\mathrm{Cpx}+\mathrm{Qz}+$ glass & $102.5 \pm 2.3$ & 3.5 & -13.9 to -9.2 \\
\hline BK8.3 & Latite & $\mathrm{Pl}+\mathrm{Cpx}+\mathrm{Amp}+\mathrm{Kfs}$ & $\mathrm{Pl}+\mathrm{Cpx}+$ glass & & & \\
\hline BK1.2 & Q-Latite & $\mathrm{Pl}+\mathrm{Kfs}+\mathrm{Cpx}$ & $\mathrm{Pl}+\mathrm{Kfs}+\mathrm{Cpx}+\mathrm{Qz}+\mathrm{Mt}+\mathrm{Ap}+$ glass & $99 \pm 2.5$ & 2.4 & -6.7 to -1.5 \\
\hline BK4.4 & Q-Latite & $\mathrm{Pl}+\mathrm{Kfs}+\mathrm{Cpx}+\mathrm{Opx}$ & $\mathrm{Pl}+\mathrm{Cpx}+\mathrm{Qz}+\mathrm{Mt}+\mathrm{Ap}+$ glass & & & \\
\hline BK4.5 & Q- Latite & $\mathrm{Pl}+\mathrm{Cpx}+\mathrm{Bt}$ & $\mathrm{Pl}+\mathrm{Cpx}+\mathrm{Qz}+$ glass & & & \\
\hline BK5.2 & Q- Latite & $\mathrm{Pl}+\mathrm{Cpx}$ & $\mathrm{Pl}+\mathrm{Cpx}+$ glass & & & \\
\hline BK8.2 & Q-Latite & $\mathrm{Pl}+\mathrm{Cpx}$ & $\mathrm{Pl}+\mathrm{Cpx}+$ glass & & & \\
\hline BK9.1 & Q- Latite & $\mathrm{Pl}+\mathrm{Cpx}+\mathrm{Bt}$ & $\mathrm{Pl}+\mathrm{Cpx}+\mathrm{Bt}+$ glass & & & \\
\hline DZH001 & Andesite & $\mathrm{Pl}+\mathrm{Amp}+\mathrm{Bt}+\mathrm{Cpx}+\mathrm{Qz}$ & $\mathrm{Pl}+\mathrm{Cpx}+\mathrm{Qz}+$ glass & $101.4 \pm 1.8$ & 2.5 & -22.6 to -4.2 \\
\hline DZH019 & Dacite & $\mathrm{Pl}+\mathrm{Amp}+\mathrm{Bt}+\mathrm{Cpx}$ & $\mathrm{Pl}+\mathrm{Cpx}+\mathrm{Bt}+\mathrm{Qz}+$ glass & $101.7 \pm 1.2$ & 0.68 & -14 to -10 \\
\hline DZH021 & Dacite & $\mathrm{Pl}+\mathrm{Amp}+\mathrm{Bt}+\mathrm{Cpx}$ & $\mathrm{Pl}+\mathrm{Cpx}+\mathrm{Bt}+\mathrm{Qz}+$ glass & $102.3 \pm 1.5$ & 0.94 & -14.8 to -10.5 \\
\hline TR78 & Dacite & $\mathrm{Pl}+\mathrm{Bt}+\mathrm{Amp}+\mathrm{Cpx}$ & $\mathrm{Pl}+\mathrm{Bt}+\mathrm{Qz}+\mathrm{Mt}+$ glass & & & \\
\hline TR79 & Dacite & $\mathrm{Pl}+\mathrm{Bt}+\mathrm{Amp}+\mathrm{Cpx}$ & $\mathrm{Pl}+\mathrm{Bt}+\mathrm{Qz}+\mathrm{Mt}+$ glass & & & \\
\hline TR80 & Dacite & $\mathrm{Pl}+\mathrm{Bt}+\mathrm{Amp}+\mathrm{Cpx}$ & $\mathrm{Pl}+\mathrm{Bt}+\mathrm{Qz}+\mathrm{Mt}+$ glass & & & \\
\hline TR81 & Dacite & $\mathrm{Pl}+\mathrm{Bt}+\mathrm{Amp}+\mathrm{Opx}+\mathrm{Cpx}$ & $\mathrm{Pl}+\mathrm{Cpx}+\mathrm{Bt}+\mathrm{Qz}+\mathrm{Mt}+$ glass & & & \\
\hline TR82 & Dacite & $\mathrm{Pl}+\mathrm{Bt}+\mathrm{Amp}+\mathrm{Cpx}$ & $\mathrm{Pl}+\mathrm{Bt}+\mathrm{Qz}+$ glass & & & \\
\hline TR83 & Dacite & $\mathrm{Pl}+\mathrm{Bt}+\mathrm{Amp}+\mathrm{Cpx}$ & $\mathrm{Pl}+\mathrm{Bt}+\mathrm{Qz}+$ glass & $104 \pm 1.6$ & 0.68 & \\
\hline BK9.4 & Dacite & $\mathrm{Pl}+\mathrm{Cpx}+\mathrm{Bt}$ & $\mathrm{Pl}+\mathrm{Cpx}+$ glass & & & \\
\hline BK5.3 & Dacite & $\mathrm{Pl}$ & $\mathrm{Pl}+\mathrm{Cpx}+$ glass & & & \\
\hline BK4.6 & Dacite & $\mathrm{Pl}+\mathrm{Cpx}$ & $\mathrm{Pl}+\mathrm{Cpx}+$ glass & & & \\
\hline BK6.6 & Dacite & $\mathrm{Pl}+\mathrm{Cpx}$ & $\mathrm{Pl}+\mathrm{Cpx}+$ glass & & & \\
\hline BK6.7 & Dacite & $\mathrm{Pl}+\mathrm{Amp}+\mathrm{Bt}++\mathrm{Cpx}+\mathrm{Qz}$ & $\mathrm{Pl}+\mathrm{Qz}+\mathrm{Cpx}+\mathrm{Bt}+$ glass & & & \\
\hline \multicolumn{7}{|c|}{ Ganjibay formation } \\
\hline BK10.1 & Dacite & $\mathrm{Pl}+\mathrm{Bt}+\mathrm{Cpx}$ & $\mathrm{Pl}+\mathrm{Qz}+\mathrm{Bt}+$ glass & & & \\
\hline BK10.2 & Dacite & $\mathrm{Pl}+\mathrm{Bt}+\mathrm{Cpx}$ & $\mathrm{Pl}+\mathrm{Qz}+\mathrm{Bt}+$ glass & & & \\
\hline BK10.3 & Dacite & $\mathrm{Pl}+\mathrm{Bt}+\mathrm{Cpx}$ & $\mathrm{Pl}+\mathrm{Qz}+\mathrm{Bt}+$ glass & & & \\
\hline KZ1-01 & Dacite & $\mathrm{Pl}+\mathrm{Bt}+\mathrm{Amp}+\mathrm{Cpx}+\mathrm{Qz}$ & $\mathrm{Pl}+\mathrm{Bt}+\mathrm{Qz}+\mathrm{Mt}+$ glass & $103.9 \pm 1.9$ & 0.34 & \\
\hline BK10.4 & Dacite & $\mathrm{Pl}+\mathrm{Bt}+\mathrm{Cpx}$ & $\mathrm{Pl}+\mathrm{Qz}+\mathrm{Bt}+$ glass & $107.1 \pm 2.3$ & 1.6 & -12.1 to -2.9 \\
\hline KZ1-03 & Dacite & $\mathrm{Pl}+\mathrm{Bt}+\mathrm{Amp}+\mathrm{Cpx}+\mathrm{Qz}$ & $\mathrm{Pl}+\mathrm{Bt}+\mathrm{Qz}+\mathrm{Mt}+$ glass & & & \\
\hline SR001 & Dacite & $\mathrm{Pl}+\mathrm{Kfs}+\mathrm{Cpx}$ & $\mathrm{Pl}+\mathrm{Cpx}+\mathrm{Qz}+$ glass & $109.3 \pm 1.9$ & 1.07 & \\
\hline DZH007 & Dacite & $\mathrm{Pl}+\mathrm{Amp}+\mathrm{Cpx}+\mathrm{Bt}$ & $\mathrm{Pl}+\mathrm{Cpx}+\mathrm{Bt}+\mathrm{Qz}+$ glass & $109.6 \pm 1.7$ & 0.73 & -14 to -8.9 \\
\hline
\end{tabular}


Table 2 Representative major (wt\%) and trace element (ppm) data for the KIC volcanic rocks from the Southern Pamir.

\begin{tabular}{|c|c|c|c|c|c|c|c|c|c|c|c|}
\hline \multirow[t]{2}{*}{ Sample } & BK 1.1 & TR85 & BK 3.1 & BK 5.4 & TR83 & TR80 & TR78 & TR82 & DZH007 & KZ1-03 & SR001 \\
\hline & \multicolumn{3}{|c|}{ Tashbulak formation } & \multicolumn{5}{|c|}{ Julbeles formation } & \multicolumn{3}{|c|}{ Ganjibay formation } \\
\hline $\mathrm{SiO} 2$ & 59.27 & 63.76 & 68.67 & 56.17 & 62.56 & 62.74 & 63.22 & 63.69 & 61.93 & 63.11 & 64.63 \\
\hline $\mathrm{TiO} 2$ & 0.80 & 0.62 & 0.40 & 0.94 & 0.69 & 0.66 & 0.66 & 0.65 & 0.70 & 0.63 & 0.59 \\
\hline $\mathrm{Al} 2 \mathrm{O} 3$ & 16.15 & 16.25 & 14.59 & 15.41 & 16.46 & 16.14 & 16.03 & 16.33 & 16.48 & 15.99 & 15.61 \\
\hline $\mathrm{Fe} 2 \mathrm{O} 3$ & 6.21 & 4.73 & 3.19 & 7.75 & 5.08 & 5.05 & 5.07 & 4.93 & 5.36 & 4.94 & 4.45 \\
\hline $\mathrm{MnO}$ & 0.10 & 0.09 & 0.05 & 0.13 & 0.09 & 0.09 & 0.09 & 0.09 & 0.10 & 0.06 & 0.07 \\
\hline $\mathrm{MgO}$ & 3.55 & 2.17 & 0.95 & 5.50 & 2.35 & 2.37 & 2.43 & 2.32 & 2.56 & 2.71 & 2.01 \\
\hline $\mathrm{CaO}$ & 4.38 & 4.33 & 1.21 & 6.98 & 4.46 & 4.42 & 4.47 & 4.38 & 4.79 & 3.88 & 3.64 \\
\hline $\mathrm{Na} 2 \mathrm{O}$ & 2.98 & 2.67 & 2.80 & 2.14 & 2.75 & 2.62 & 2.66 & 2.78 & 2.72 & 2.57 & 2.89 \\
\hline $\mathrm{K} 2 \mathrm{O}$ & 3.74 & 3.55 & 5.65 & 3.51 & 3.75 & 3.87 & 3.79 & 3.69 & 3.52 & 3.98 & 3.71 \\
\hline $\mathrm{P} 2 \mathrm{O} 5$ & 0.28 & 0.21 & 0.15 & 0.30 & 0.22 & 0.22 & 0.22 & 0.22 & 0.23 & 0.22 & 0.21 \\
\hline L.O.I & 2.20 & 1.20 & 2.03 & 0.80 & 0.68 & 0.68 & 0.60 & 0.74 & 0.64 & 1.66 & 1.83 \\
\hline Total & 99.67 & 99.57 & 99.69 & 99.63 & 99.08 & 98.86 & 99.24 & 99.82 & 99.03 & 99.75 & 99.62 \\
\hline Mg\# & 53.1 & 47.6 & 37.1 & 58.4 & 47.8 & 48.2 & 48.7 & 48.2 & 48.6 & 52.1 & 47.2 \\
\hline $\mathrm{Sc}$ & 19.53 & 14.54 & 5.74 & 2.89 & 16.02 & 16.31 & 16.06 & 15.55 & 16.49 & 16.42 & 13.36 \\
\hline $\mathrm{Cr}$ & 68.6 & 45.27 & 9.97 & 3.18 & 55.1 & 47.3 & 53.24 & 46.37 & 47.3 & 51.85 & 34.61 \\
\hline Co & 12.71 & 8.85 & 3.42 & 0.86 & 9.83 & 10.07 & 10.08 & 9.58 & 9.85 & 9.79 & 9.93 \\
\hline $\mathrm{Ni}$ & 6.62 & 4.24 & 2.21 & 0.86 & 4.98 & 4.46 & 5.26 & 4.28 & 4.58 & 6.18 & 9.07 \\
\hline $\mathrm{Cu}$ & 6.74 & 2.57 & 4.98 & 17.28 & 6.34 & 5.79 & 6.42 & 5.50 & 7.50 & 4.72 & 3.95 \\
\hline $\mathrm{Zn}$ & 47.3 & 59.5 & 40.5 & 16.8 & 66.2 & 68.8 & 67.1 & 61.1 & 63.7 & 64.6 & 24.8 \\
\hline $\mathrm{Rb}$ & 152 & 136 & 212 & 212 & 157 & 174 & 164 & 153 & 133 & 173 & 175 \\
\hline $\mathrm{Sr}$ & 581 & 481 & 184 & 308 & 473 & 484 & 487 & 488 & 486 & 452 & 494 \\
\hline $\mathrm{Y}$ & 21.3 & 20.9 & 16.0 & 19.0 & 22.4 & 21.1 & 20.8 & 22.1 & 22.6 & 20.6 & 22.7 \\
\hline $\mathrm{Zr}$ & 182 & 203 & 247 & 226 & 203 & 207 & 215 & 223 & 215 & 191 & 195 \\
\hline $\mathrm{Nb}$ & 12.3 & 13.5 & 13.6 & 15.3 & 14.5 & 14.0 & 14.0 & 14.3 & 14.0 & 13.1 & 14.2 \\
\hline Cs & 6.54 & 2.82 & 7.59 & 5.28 & 5.94 & 6.28 & 5.22 & 5.14 & 3.90 & 7.77 & 2.23 \\
\hline $\mathrm{Ba}$ & 780 & 761 & 1000 & 610 & 846 & 842 & 833 & 822 & 829 & 826 & 864 \\
\hline $\mathrm{La}$ & 29.7 & 38.0 & 36.9 & 30.9 & 38.7 & 39.3 & 38.6 & 39.5 & 35.6 & 39.4 & 53.1 \\
\hline $\mathrm{Ce}$ & 61.1 & 74.6 & 75.4 & 57.9 & 77.1 & 77.9 & 75.5 & 77.8 & 72.8 & 77.0 & 103.3 \\
\hline $\operatorname{Pr}$ & 6.88 & 8.12 & 7.85 & 6.41 & 8.48 & 8.37 & 8.18 & 8.50 & 8.10 & 8.26 & 10.94 \\
\hline $\mathrm{Nd}$ & 30.2 & 30.1 & 32.8 & 26.4 & 32.0 & 30.8 & 30.1 & 31.5 & 31.0 & 30.5 & 39.5 \\
\hline $\mathrm{Sm}$ & 5.99 & 5.71 & 5.78 & 4.89 & 6.17 & 5.93 & 5.84 & 6.03 & 6.17 & 5.75 & 7.30 \\
\hline $\mathrm{Eu}$ & 1.41 & 1.29 & 0.98 & 1.02 & 1.33 & 1.30 & 1.31 & 1.33 & 1.36 & 1.33 & 1.44 \\
\hline $\mathrm{Gd}$ & 6.14 & 5.26 & 6.04 & 4.99 & 5.61 & 5.32 & 5.24 & 5.54 & 5.44 & 5.09 & 6.45 \\
\hline $\mathrm{Tb}$ & 0.67 & 0.68 & 0.55 & 0.58 & 0.73 & 0.68 & 0.67 & 0.71 & 0.72 & 0.67 & 0.78 \\
\hline Dy & 4.13 & 3.73 & 3.27 & 3.62 & 4.03 & 3.77 & 3.72 & 3.93 & 4.05 & 3.75 & 4.15 \\
\hline Ho & 0.73 & 0.72 & 0.56 & 0.68 & 0.78 & 0.72 & 0.72 & 0.75 & 0.78 & 0.71 & 0.78 \\
\hline $\mathrm{Er}$ & 2.33 & 2.08 & 1.82 & 2.23 & 2.25 & 2.11 & 2.10 & 2.23 & 2.26 & 2.11 & 2.18 \\
\hline $\mathrm{Tm}$ & 0.31 & 0.32 & 0.25 & 0.35 & 0.35 & 0.32 & 0.32 & 0.34 & 0.34 & 0.31 & 0.35 \\
\hline $\mathrm{Yb}$ & 2.17 & 2.08 & 1.78 & 2.44 & 2.21 & 2.09 & 2.09 & 2.22 & 2.23 & 2.07 & 2.13 \\
\hline $\mathrm{Lu}$ & 0.30 & 0.31 & 0.25 & 0.36 & 0.34 & 0.31 & 0.32 & 0.33 & 0.33 & 0.31 & 0.32 \\
\hline Hf & 4.58 & 5.28 & 6.43 & 6.59 & 5.40 & 4.97 & 5.19 & 5.65 & 5.72 & 4.64 & 4.73 \\
\hline $\mathrm{Ta}$ & 0.77 & 1.06 & 0.94 & 1.09 & 1.12 & 1.00 & 1.02 & 1.08 & 1.04 & 0.94 & 1.07 \\
\hline $\mathrm{Pb}$ & 12.10 & 21.72 & 23.47 & 13.70 & 23.83 & 21.80 & 22.18 & 19.99 & 20.11 & 23.52 & 9.71 \\
\hline Th & 11.69 & 16.77 & 22.89 & 22.68 & 15.74 & 15.75 & 15.63 & 16.42 & 14.94 & 15.78 & 24.32 \\
\hline $\mathrm{U}$ & 2.80 & 3.72 & 4.12 & 4.63 & 3.15 & 3.17 & 3.08 & 3.45 & 3.20 & 3.54 & 5.44 \\
\hline
\end{tabular}


Table 3 Whole - rock Sr - Nd isotopic ratios of the KIC volcanic rocks from the Southern Pamir

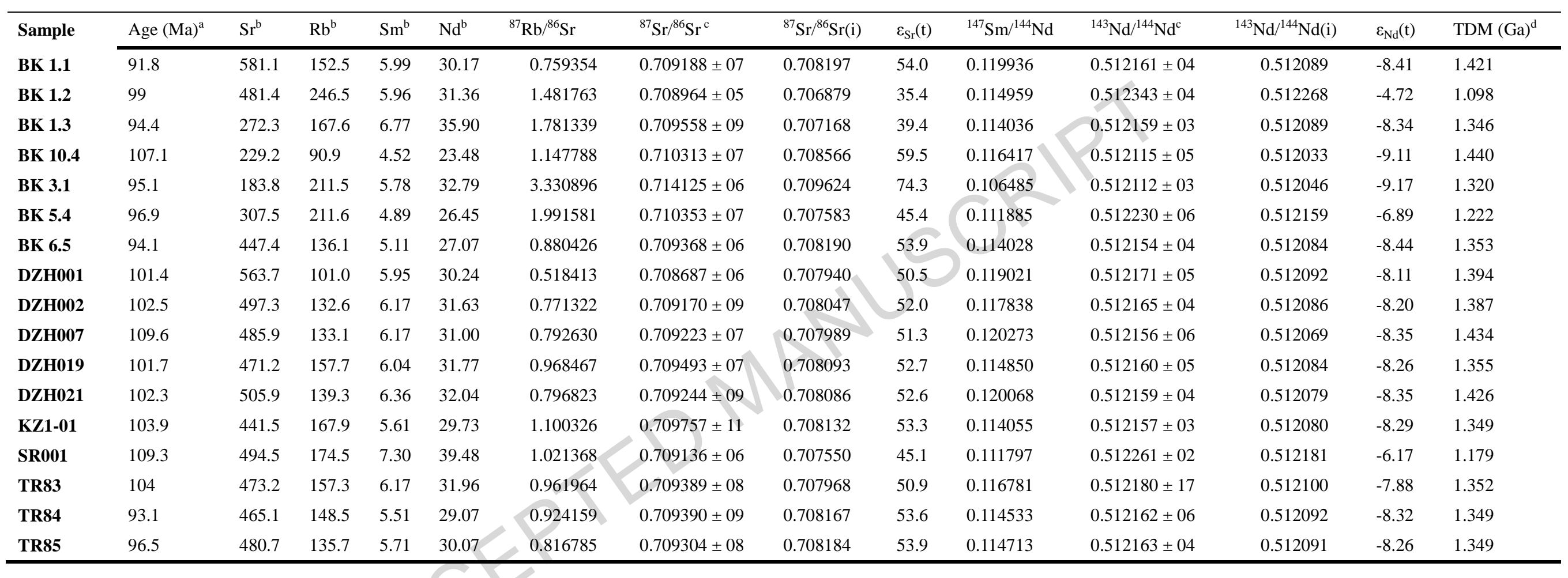

${ }^{a}$ Age, zircon weighted mean age $\left({ }^{206} \mathrm{~Pb} /{ }^{238} \mathrm{U}\right)$

${ }^{b}$ Concentrations of $\mathrm{Rb}, \mathrm{Sr}, \mathrm{Sm}$ and $\mathrm{Nd}$ are in $\mathrm{ppm}$

${ }^{c}$ Errors are $2 \sigma$

${ }^{d}$ TDM, depleted mantle model ages 


\section{Figure 1}

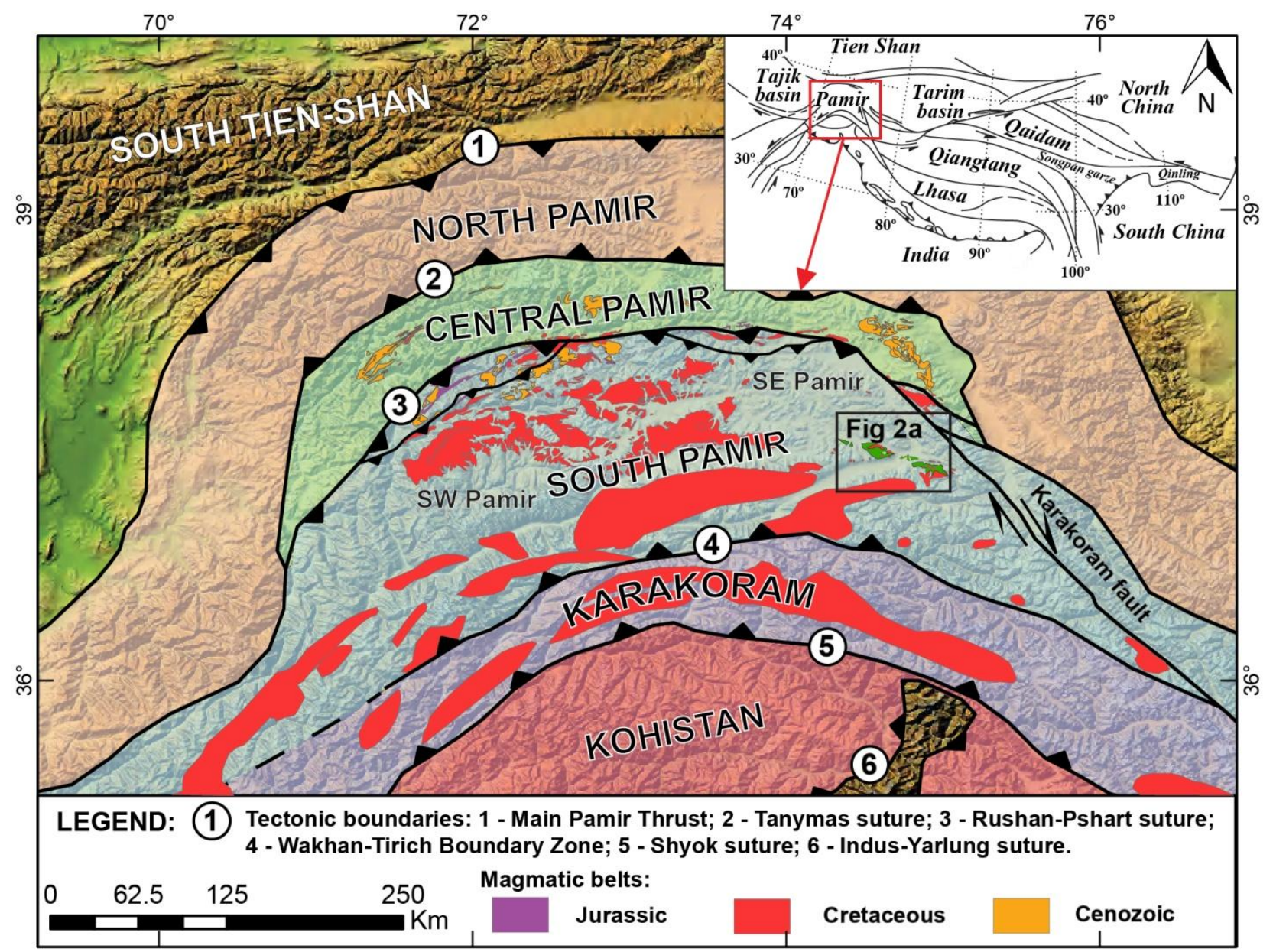


Figure 2

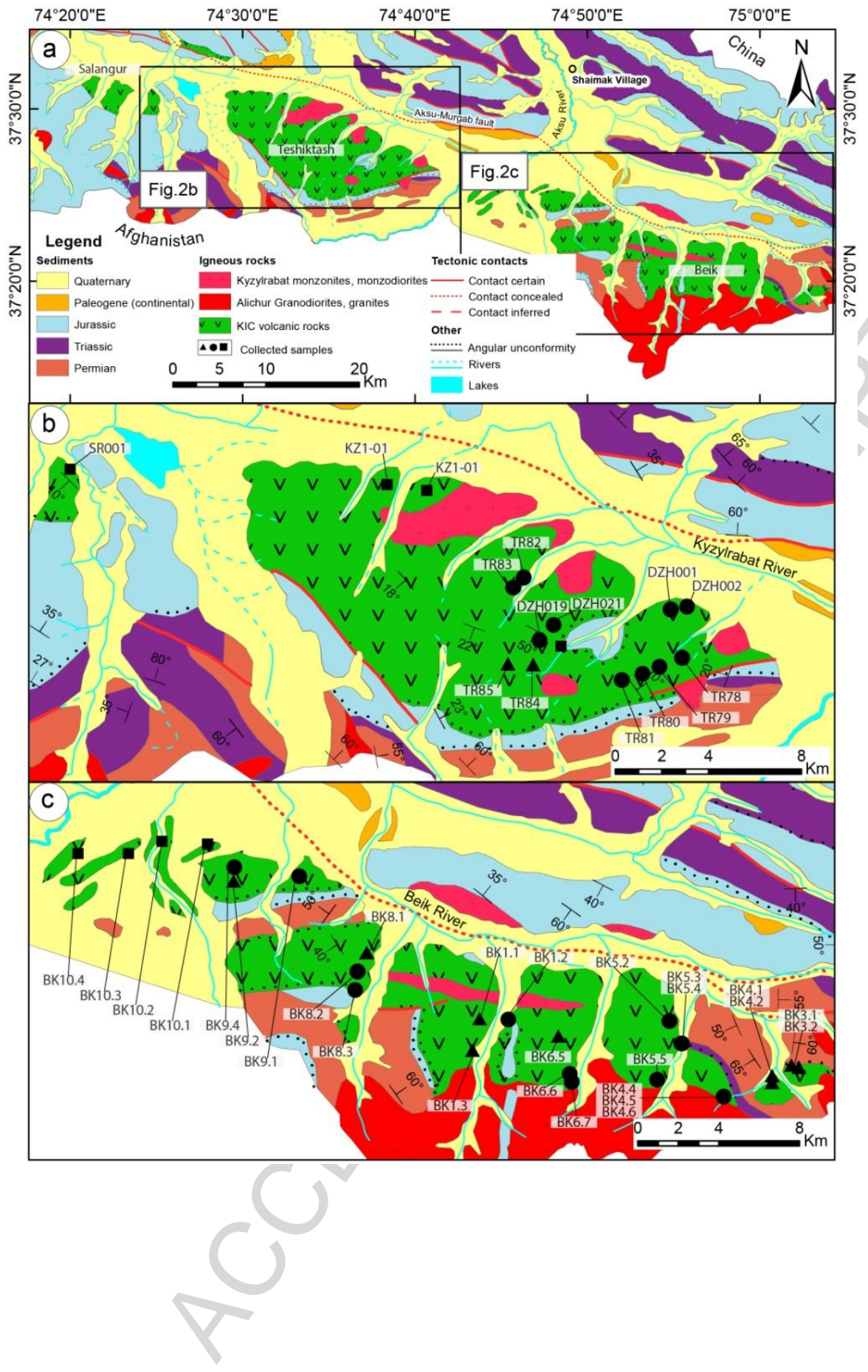


Figure 3
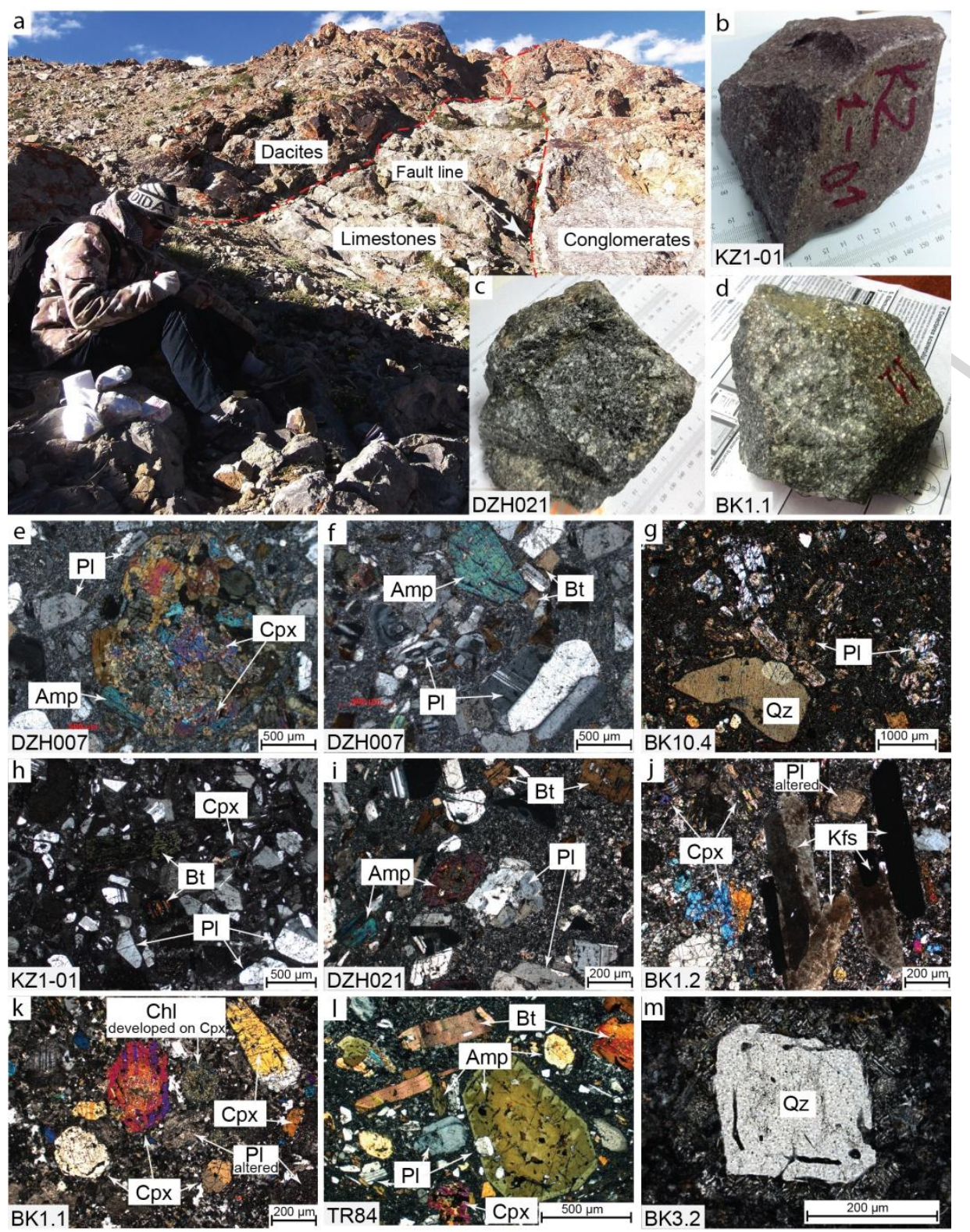


\section{Figure 4}
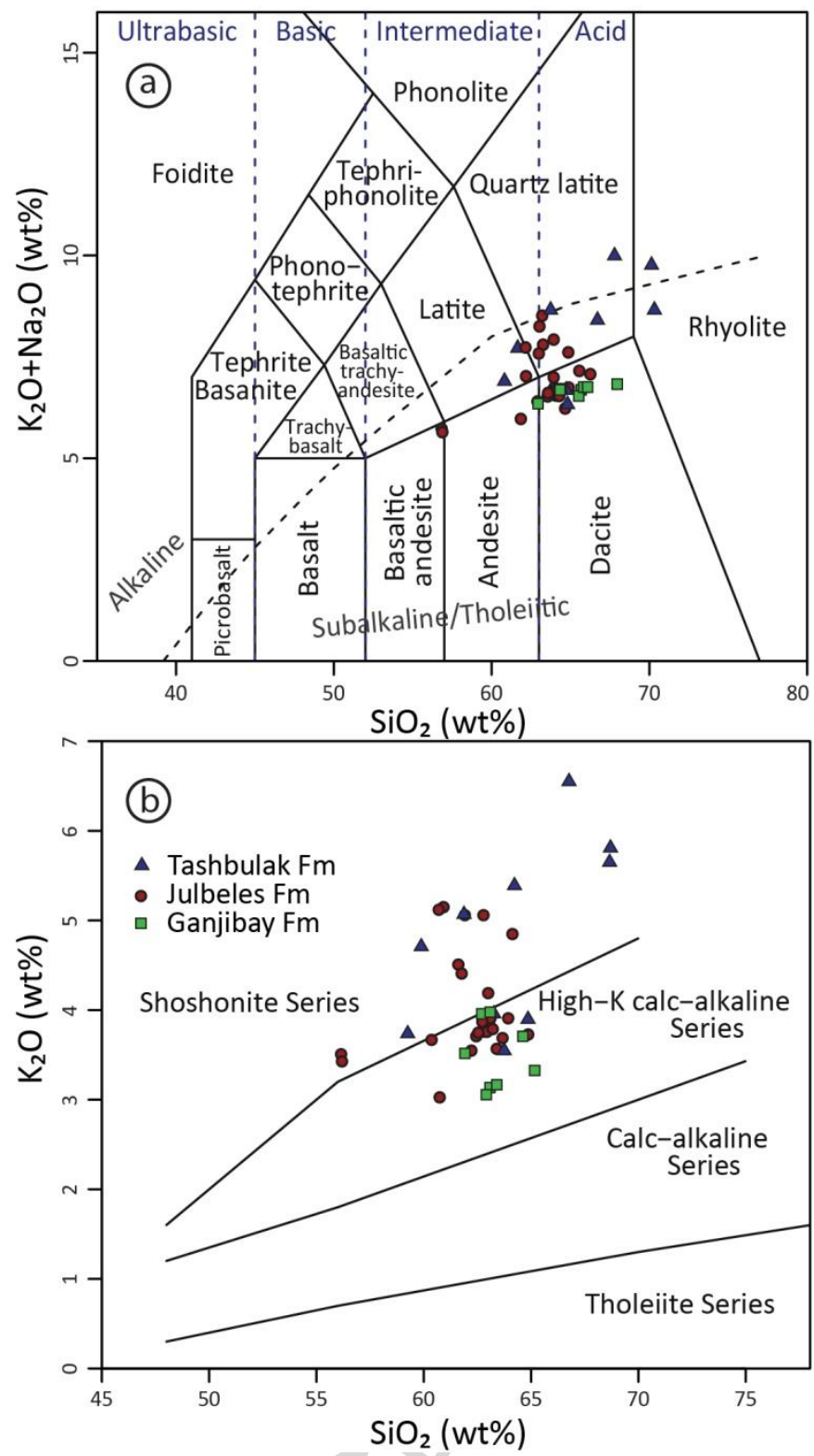
Figure 5

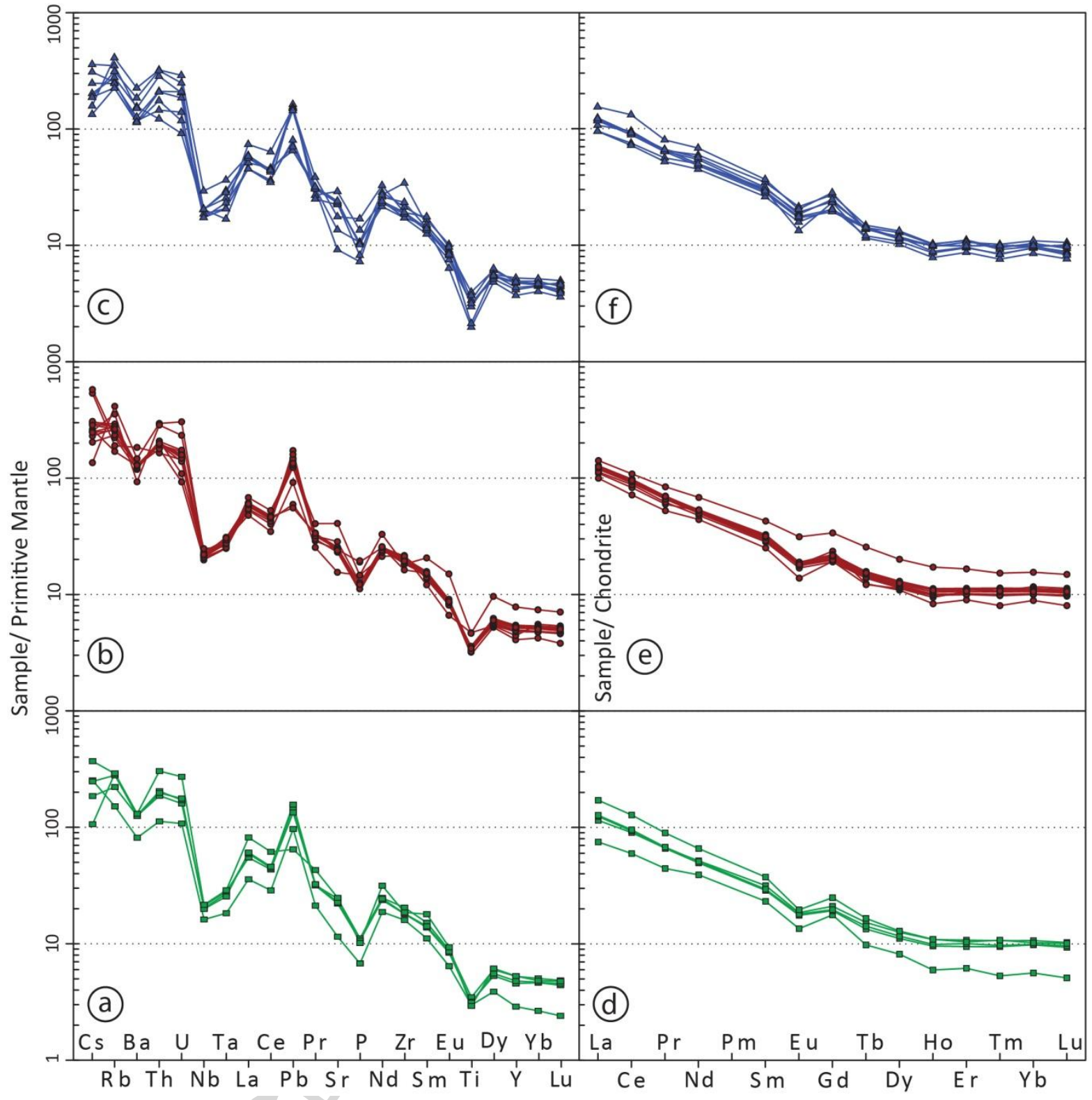




\section{Figure 6}

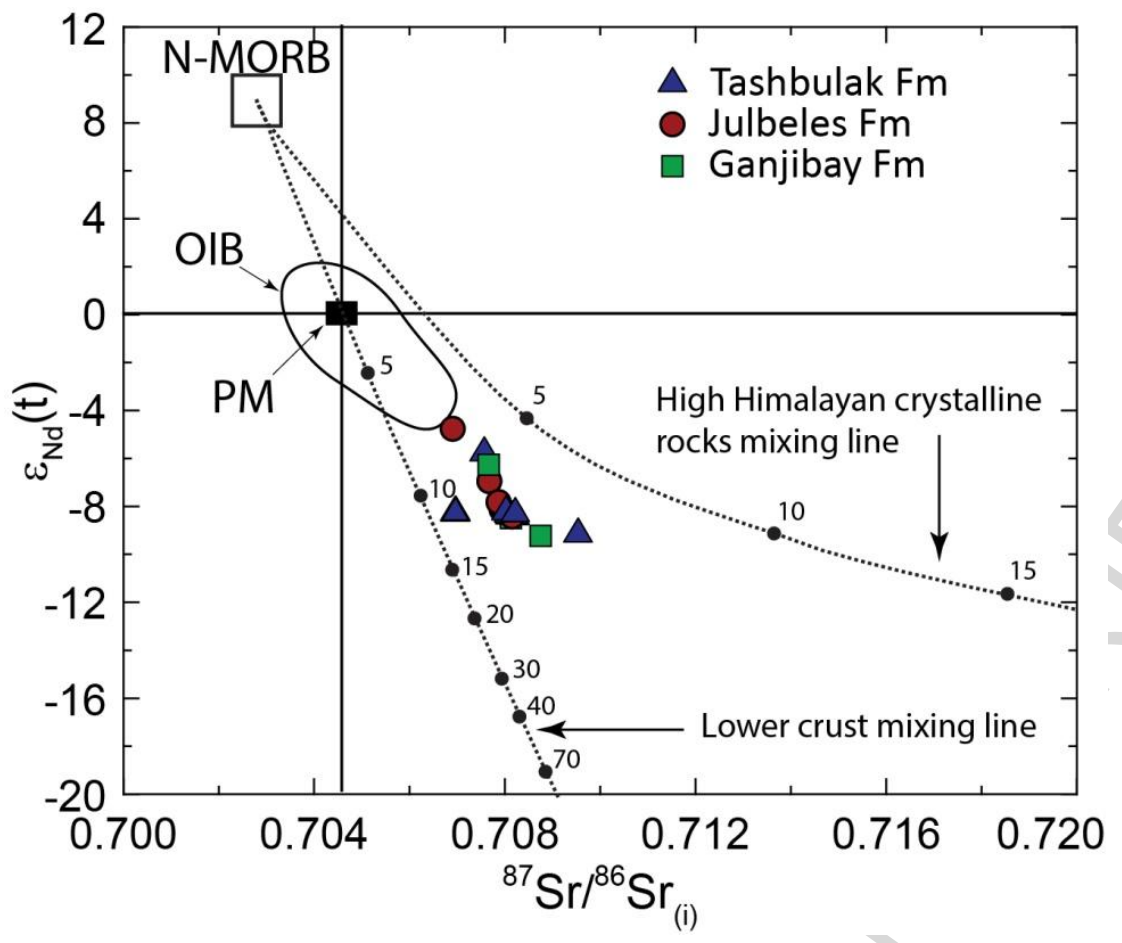


Figure 7
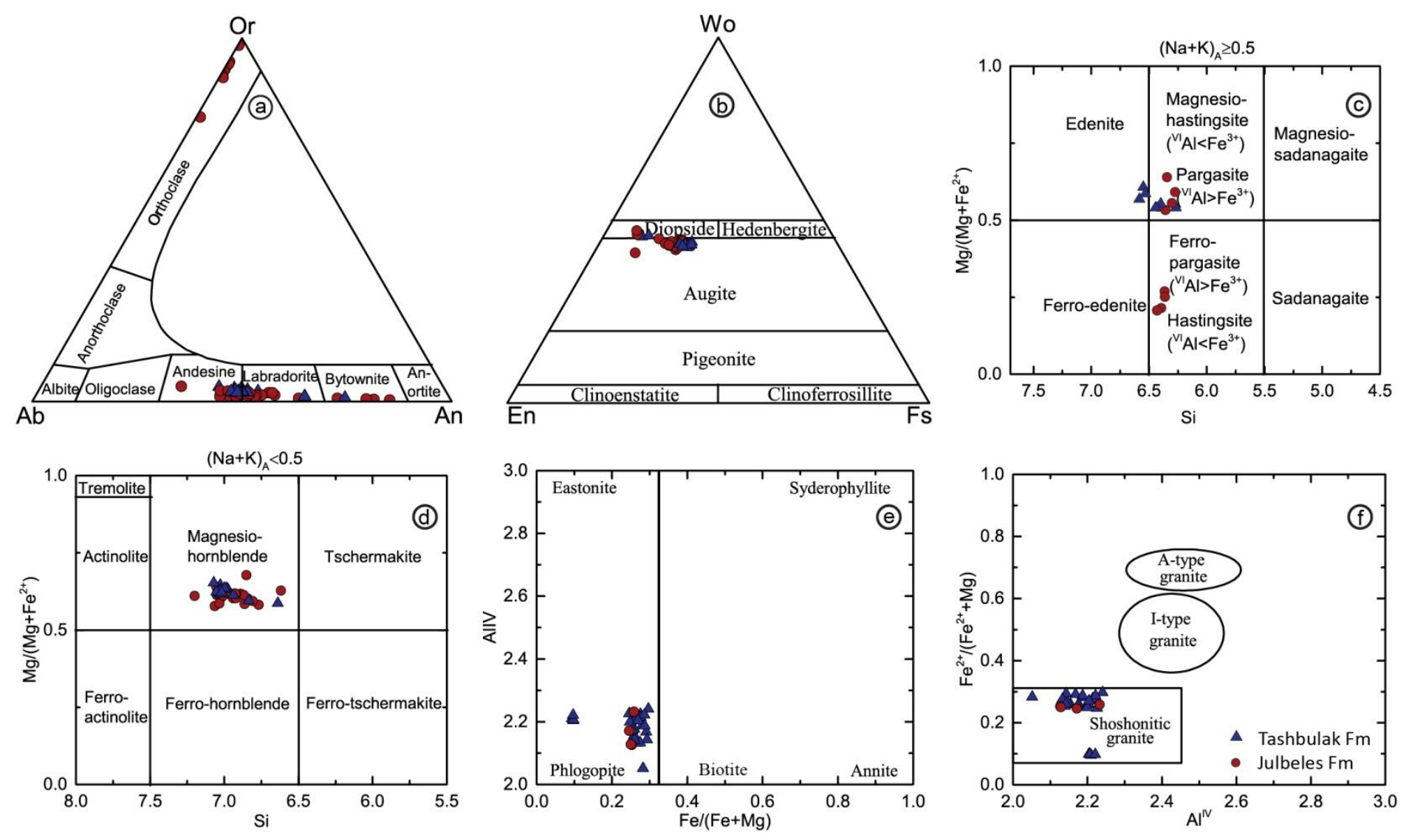
Figure 8
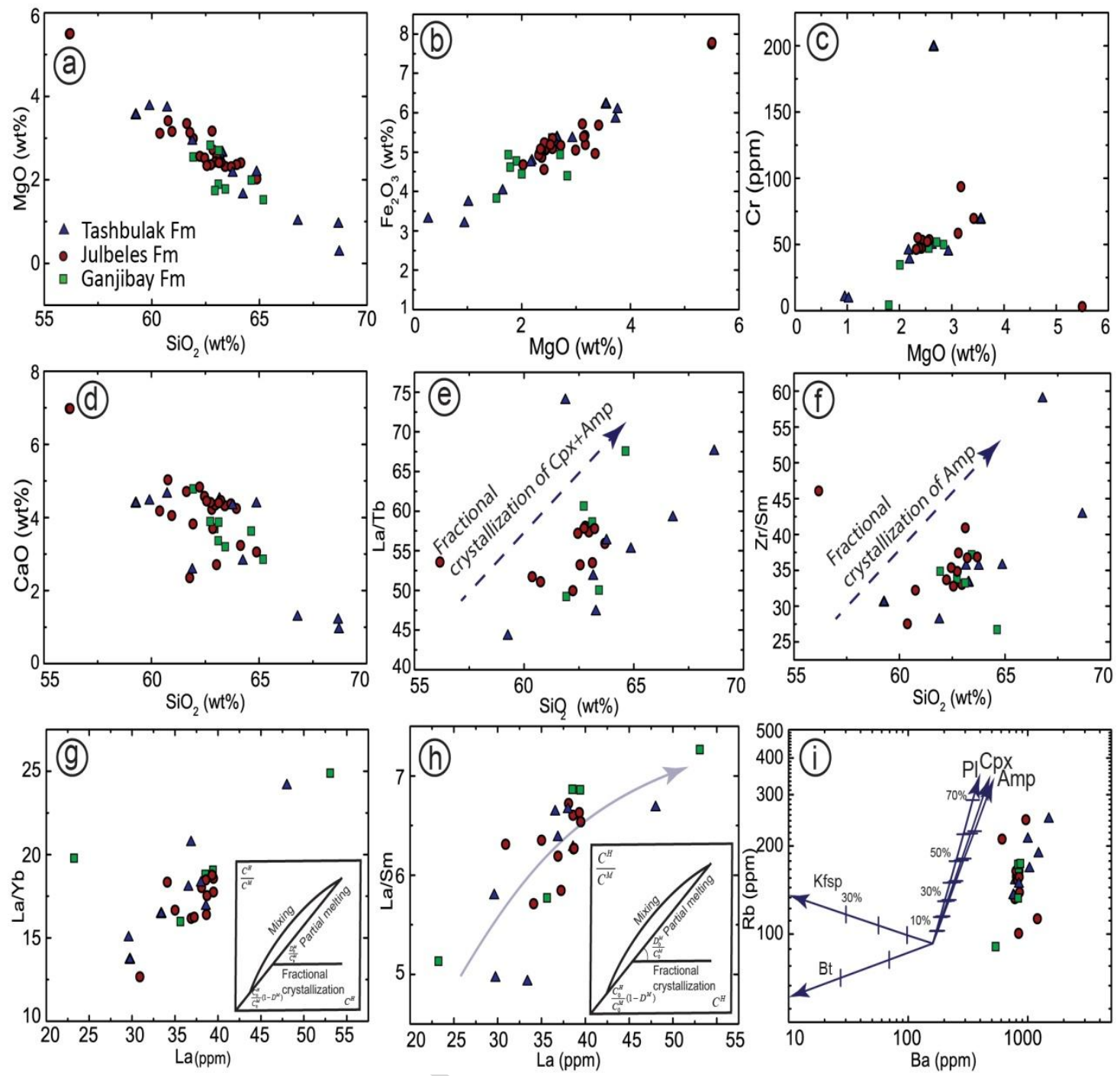
Figure 9

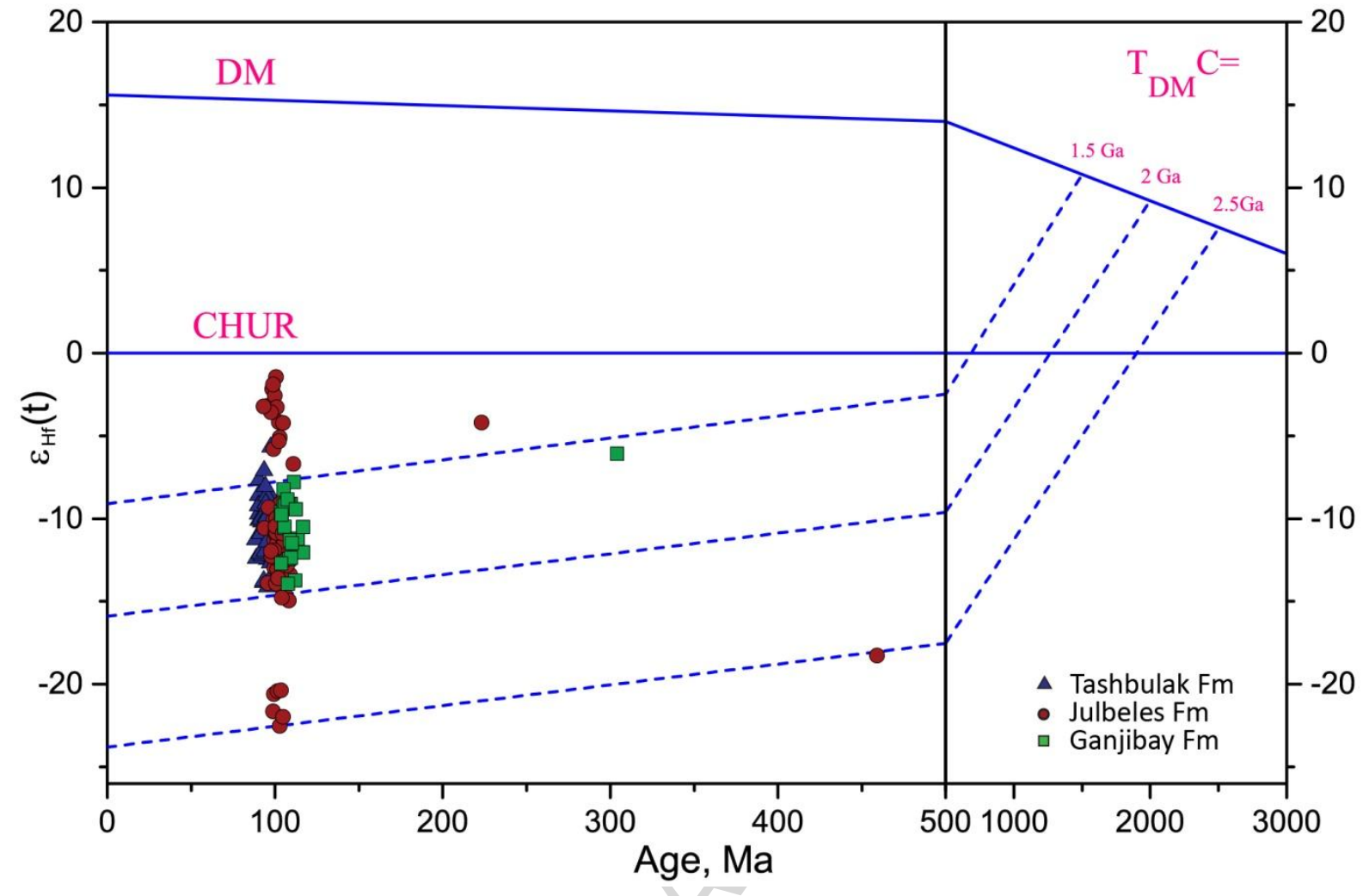




\section{Figure 10}
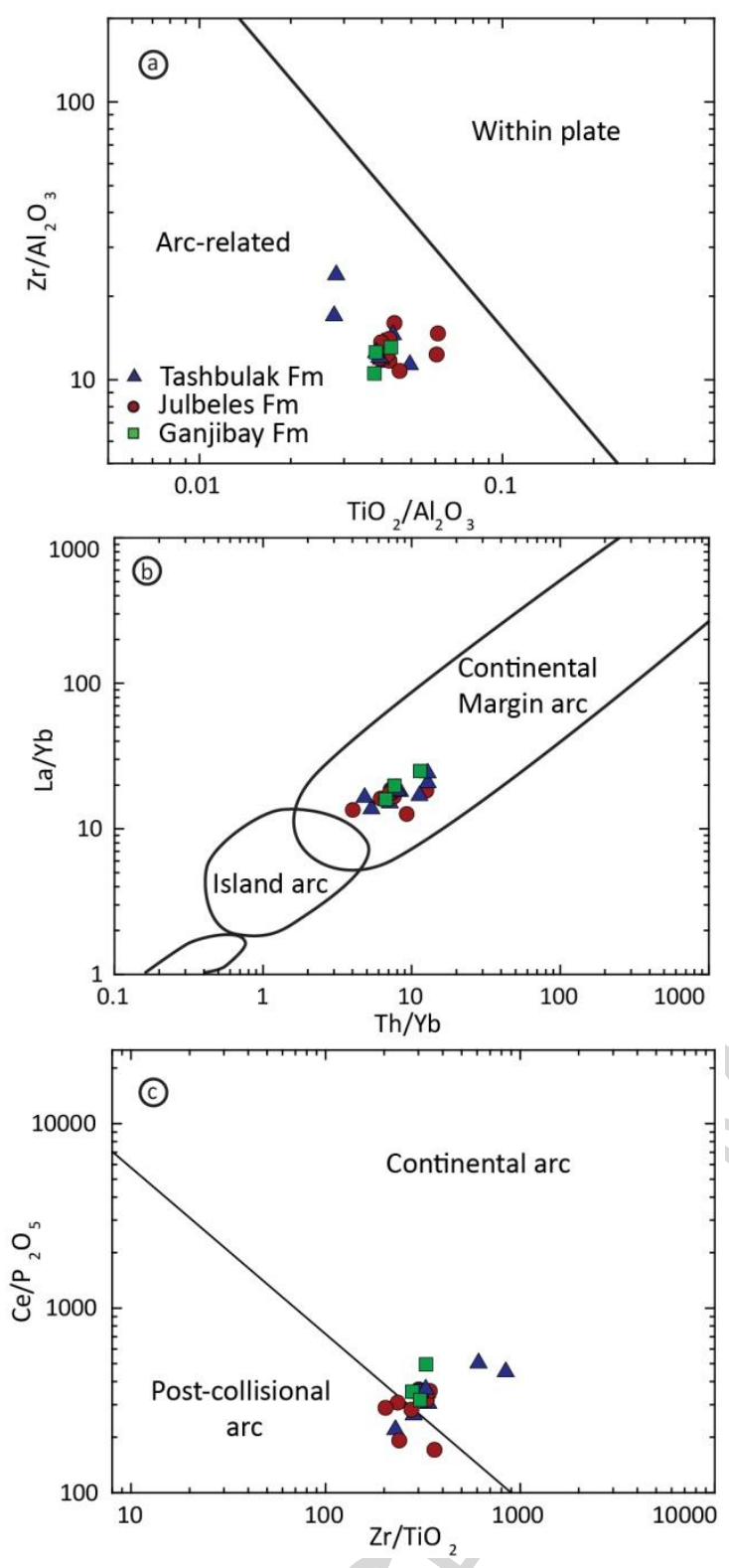


\section{Figure 11}

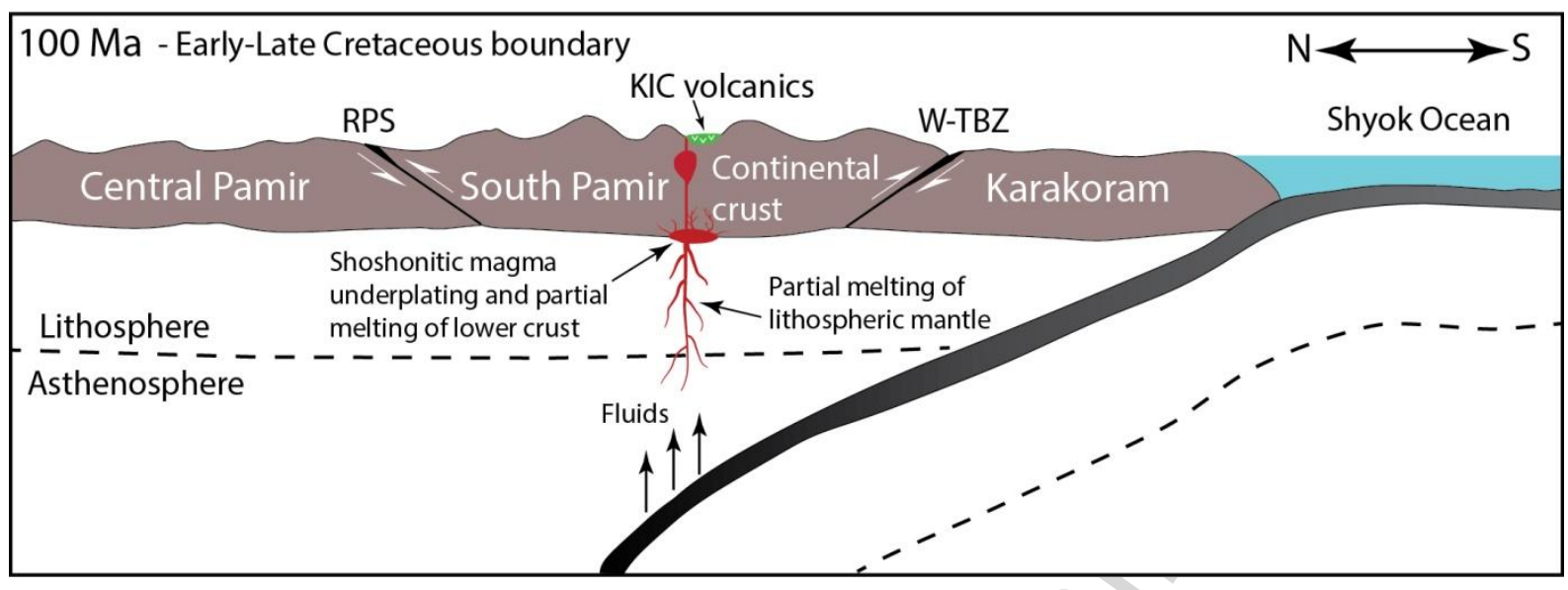




\section{Graphical abstract}

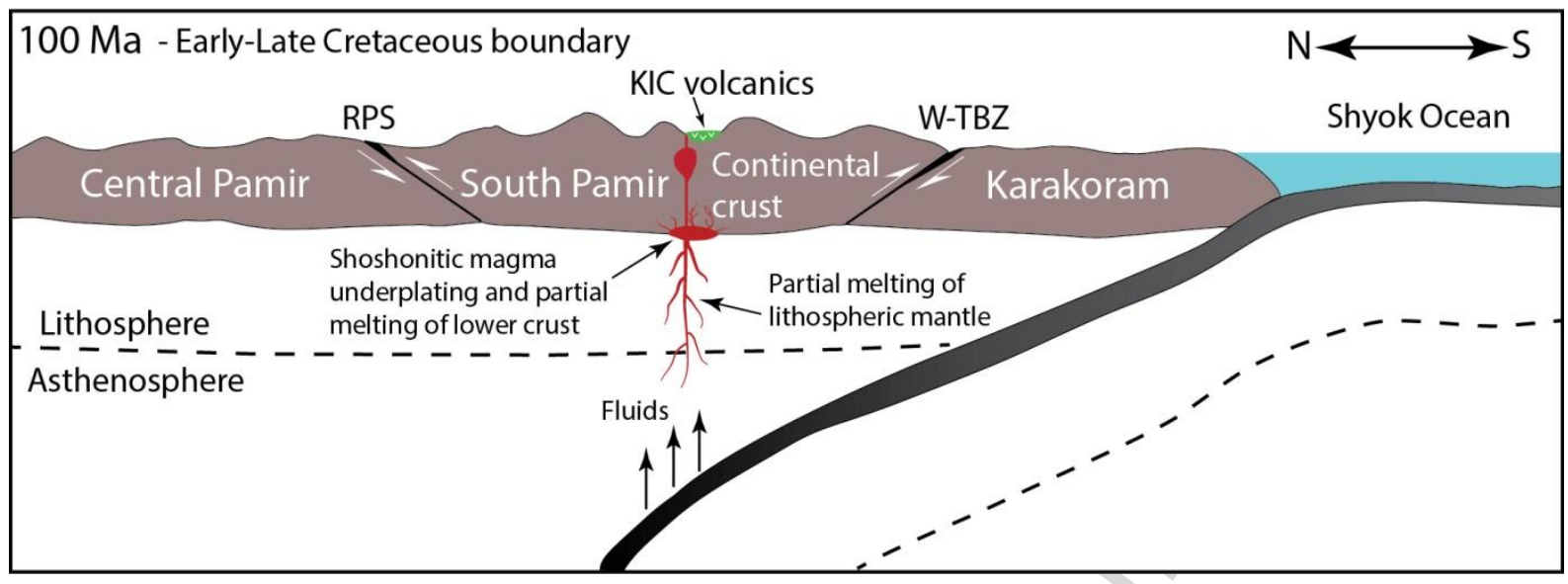




\section{Highlights:}

- The geochemistry and age of the Southern Pamir 110-92 Ma volcanic sequence is studied.

- Results provide evidence for subduction-collision transition along the Shyok suture.

- A significant part of the crustal thickening in the Pamir occurred in the Mesozoic. 